\title{
THE
}

\section{Antecedents and consequences of Personal Financial Management Behavior: a systematic literature review and future research agenda}

\author{
Kirti Goyal \\ Satish Kumar \\ Jing Jian Xiao \\ University of Rhode Island, jjxiao@uri.edu
}

Follow this and additional works at: https://digitalcommons.uri.edu/hdf_facpubs

The University of Rhode Island Faculty have made this article openly available.

Please let us know how Open Access to this research benefits you.

This is a pre-publication author manuscript of the final, published article.

Terms of Use

This article is made available under the terms and conditions applicable towards Open Access

Policy Articles, as set forth in our Terms of Use.

\section{Citation/Publisher Attribution}

Goyal, K., Kumar, S. and Xiao, J.J. (2021), "Antecedents and consequences of Personal Financial Management Behavior: a systematic literature review and future research agenda", International Journal of Bank Marketing, Vol. ahead-of-print No. ahead-of-print. https://doi.org/10.1108/IJBM-12-2020-0612 Available at: https://doi.org/10.1108/IJBM-12-2020-0612

This Article is brought to you for free and open access by the Human Development and Family Science at DigitalCommons@URI. It has been accepted for inclusion in Human Development and Family Science Faculty Publications by an authorized administrator of DigitalCommons@URI. For more information, please contact digitalcommons-group@uri.edu. 


\title{
Accepted for Publication
}

\section{International Journal of Bank Marketing}

\author{
(ABDC-A, ABS-2, SSCI Indexed, IF=2.8)
}

\section{Antecedents and Consequences of Personal Financial Management} Behavior: A Systematic Literature Review and Future Research Agenda

\author{
Kirti Goyal, Satish Kumar* and Jing Jian Xiao
}

1. Kirti Goyal, Research Scholar, Department of Management Studies, Malaviya National Institute of Technology Jaipur, Rajasthan, 302017, India. Email: 2019RBM9185@mnit.ac.in

2. Corresponding Author*: Satish Kumar, Associate Professor of Finance, Department of Management Studies, Malaviya National Institute of Technology Jaipur, Rajasthan, 302017, India Email: skumar.dms@mnit.ac.in

Adjunct Associate Professor, Swinburne University of Technology, Swinburne Business School, Jalan Simpang Tiga, 93350 Kuching, Sarawak, MALAYSIA

3. Jing Jian Xiao, Professor, Department of Human Development and Family Science, University of Rhode Island, Kingston, RI 02881, USA. Email: jjxiao@uri.edu 


\title{
Antecedents and Consequences of Personal Financial Management Behavior: A Systematic Literature Review and Future Research Agenda
}

\begin{abstract}
Purpose - The purpose of this paper is to investigate the current state of research on Personal Financial Management Behavior (PFMB), with a prime focus on its antecedents and the consequences. By analyzing the research trends, methods, determinants, and outcomes, the PFMB literature is synthesized, and agenda for future research is suggested. A framework is presented that portrays PFMB's antecedents and consequences and further specification of the mediation and moderation linkages.
\end{abstract}

Design/Methodology/approach - The review is based on 160 articles published during 19702020. It follows a systematic approach and presents the definitions and theories of PFMB, publication trends based on time, region, sample population, research designs, data collection and analysis techniques, along with antecedents and outcomes through content analysis.

Findings - The synthesis draws upon various factors affecting PFMB, such as demographics, socio-economic, psychological, social, cultural, financial experience, financial literacy (FL), and technological factors. The prominent outcomes of PFMB include financial satisfaction, relationship satisfaction, quality of life, financial success, happiness, financial vulnerability/resilience, and financial well-being. The future research agenda sums up the recommendations in the form of research questions on variables and their linkages, followed by methodological advancements.

Originality/value - This paper covers the scholarly work done in this area in the past 51 years. To the best of authors' knowledge, this is the first attempt to offer a most comprehensive and collective scholarship of this subject. It further gives an extensive future research agenda.

Keywords Systematic literature review, Personal financial management behavior, Financial management behavior, Financial behavior

Paper type: Literature review 


\section{Introduction}

In today's modernized age with all facets of development, people own much more money than in the past. Robust financial health and overall well-being lead to the objectives of an individual's life (Boon et al., 2011). Furthermore, with an upsurge in cost of living, complexities in making financial choices, liberal credit, and social security reforms, it is imperative that people take charge of planning and managing their finances in their own best interest (Xu and Zia, 2012). "Personal Financial Management Behavior (PFMB) is a process which assimilates all components of individuals' financial interest. These include cash flow management, investments, risk management, retirement planning, tax planning, and estate planning" (Altfest, 2004, p.54). Robust PFMB would make individuals sense security and, eventually, financial freedom (Hilgert et al., 2003). Missteps in managing personal finances can have a profound long-term impact (Estelami, 2014). Recently, unsuccessful PFMB has been avidly concerned (Lusardi et al., 2020). Individuals lack knowledge of financial concepts due to which economic decisions made by them influence their current financial well-being and future saving goals (Schuchardt et al., 2007). Building from consumer financial narratives, perceived financial well-being is conceptualized as stress over current finances and a sense of security about achieving future financial goals (Netemeyer et al., 2018).

Taking charge of finances does not only mean establishing a daily household budget but also saving and investing in building a shield for future expenses, either predictable (buying a house, car, or education) or unpredictable (loss of a job or health issues) along with assuring stressfree post-retirement years through a blanket financial plan (Kidwell and Turrisi, 2004; Copur and Gutter, 2019). In this study, PFMB is defined as a set of multi-dimensional behavioral indicators concerning the planning, implementation, and evaluation comprised in the areas of cash flow, credit, savings and investments, insurance, retirement and estate planning as well as income and money management within a household.

The pursuit of personal finance is interdisciplinary, having omnipresence in psychology, sociology, finance, economics, information technology, and family studies (Schuchartdt et al., 2007). Each discipline has diversified theories that offer diverse perspectives on individuals' and households' financial behavior and money management (Copur and Gutter, 2019). Furthermore, professionals, educators, government, and policymakers aim at developing programs that focus on providing knowledge and preparing "rational human beings" handle their finances in a better way. Nevertheless, in reality, behavioral economics, a blend of psychology and economics, endorses the part that psychological attributes play in personal financial decisions (Hilgert et al., 2003). Certain irrational behaviors such as carrying too much debt, not saving enough, and aggressive trading lead to "sub-optimal" decisions. There are significant other factors that connect to individual financial behavior such as demographics (Allgood and Walstad, 2013), socio-economic factors (Gorniak, 1999; Grable et al., 2009), social factors (shim et al., 2009), FL (Lusardi and Mitchell, 2007) and technological factors (Panos and Wilson, 2020). According to Organization for Economic Cooperation and Development (OECD), FL is defined as the "knowledge and understanding of financial concepts and risks, and the skills, motivation, and confidence to apply such knowledge and understanding in order to make effective decisions across a range of financial contexts, to improve the financial well-being of individuals and society, and to enable participation in economic life." (OECD, 2014). The voluminous prior evidence on PFMB has also concentered on its potential lifetime consequences in the form of financial well-being, security, or ultimate satisfaction (Mugenda et al., 1990; Vogler et al., 2008; Miotto and Parente, 2015; Dew et al., 2020). Such a multiplicity of literature from diverse fields has surfaced the need for a composite and systematic summarization of the existing body of knowledge on the subject. Hence, an under-researched yet significant area of PFMB interests an attempt to delve into the domain's collective scholarship. Continued research on financial behavior is needed to gain insights to 
inform future financial counseling and education efforts. Further, the topic is crucial for financial service professionals to take benefits of understanding financial management behavior in catering to the needs of their clients. Policymakers may use the information to advocate effective financial education programs to improve consumer financial well-being.

The leading aim of this paper is to compile the scholarly work on PFMB under one umbrella, fielding five principal inquiries:

$R Q 1$ : What are the existing definitions and theories of PFMB in the extant literature?

RQ2: What are the research trends in PFMB in terms of time, sample country, sample population, and structure (contents) of PFMB?

RQ3: What are the research methodologies, research designs, data collection techniques, and methods of data analysis that have been employed in PFMB research?

RQ4: What are the antecedents and consequences of PFMB?

RQ5: What are the gaps in the existing research on PFMB and scope for future research?

\section{Rationale of the study}

PFMB is a complex construct (Xiao and Tao, 2020), and for a considerable discernment of this construct, the subject was investigated broadly, following which the literature synthesis was unveiled. Based on the delineation that PFMB literature revolves around a plethora of its diverse antecedents and observable consequences, the scope of the review - the antecedents and consequences of PFMB - was decided. The extant reviews on PFMB (see Table I) focused on a single aspect of PFMB, with the majority embracing FL as a significant construct or varied widely in their review approach. In fact, the topic of PFMB is greatly overlapped with the literatures of FL (Boon et al., 2011). Huston (2010) conceptualized financial literacy as the knowledge of personal finance as well as the application of that knowledge. Mere knowledge of basic concepts of finance is futile unless it is reflected in financial behaviour (Atkinson and Messy, 2012). In fact, OECD measured FL as a combination of three constructs: financial knowledge, financial attitude, and financial behavior (OECD, 2011). Financial literacy and financial capability are used as synonyms (Kempson et al., 2006). People can be financially literate when they have knowledge, understanding, and skills to take care of their personal finances, but they cannot be called financially capable unless reflected in their actual behavior. There are several studies that provide evidence of financial behavior as an outcome of financial literacy (Lusardi and Mitchell, 2011a; Van Rooij et al., 2011; Kaiser and Menkhoff, 2017). For the purpose of this study, we considered PFMB construct as the outcome of financial literacy.

Further, we failed to track any paper putting forth a comprehensive synthesis of the PFMB literature to date. Figuring such deficiencies, this is the first attempt to provide a detailed review on PFMB, putting forth significant developments and trends in the field with antecedents and consequences as its prime focus. The review also suggests a future research agenda in this domain. This study will serve as a pool of up-to-date knowledge on PFMB for academicians. It would also help policymakers and financial educators design programs on PFM that would benefit society and the real economy.

(Insert Table I about here)

Primarily, the research methodology employed in the review has been delineated in the next section. The following section explicates the results relating to the existing definitions and theories of PFMB and research trends. Subsequently, a conceptual framework furnishes a detailed inquiry into the antecedents and consequences of PFMB. The gaps in the extant research and directions for future research are discussed in the next section. The later section expounds implications of the study, followed by wrapping up the study in the conclusion section. 


\section{Review method}

This study pursues a systematic literature review method as a reliable, replicable, and scientific way of producing a stock of knowledge that is not subject to bias (Tranfield et al., 2003). To delve into the literature, a comprehensive review equipped with content analysis canvasses the state-of-the-art literature concerning the theories, concepts, factors, and outcomes of PFMB (Goyal and Kumar, 2021). To conduct the study, we have used the two largest databases of indexed articles: Web of Science by Clarivate Analytics and Scopus. These two multidisciplinary databases are acknowledged to provide extensive results and allow for advanced search options (Rebouças and Soares, 2020). The search was conducted in August 2020. We avoided limiting the search to a specific period to retrieve all relevant papers to date.

Personal finance is the subject of how individuals, households, consumers, and families procure, develop, and allocate financial resources to achieve their present and future financial goals (Hira and Mugenda, 1999). With an intent to not skip any crucial publication for consideration in this review, a comprehensive long string of appropriate search terms was used to run the search in title, abstract, and keywords. Table II shows the search string used for data retrieval. The search in two databases Scopus and Web of Science, yielded 1137 and 523 results, respectively. Limiting the search results to the English language resulted in 1063 and 515 items, totaling 1578. Subsequently, duplicates $(n=440)$ were removed, which derived 1138 items. Upon reading the abstracts, 245 articles were retained for full paper consideration based on the relevance to the subject of PFMB. Inclusion and exclusion criteria were put to limit the articles according to the scope of the review. Out of 245 papers on PFMB, 133 studies accorded with the theme of antecedents and consequences of PFMB. Further, the references of the full papers were also scanned, and 27 relevant records were identified, which were added manually to the list after reading abstracts. The complementary search is helpful in identifying the studies that might have been missed in the primary database search (Harari et al., 2020). Finally, 160 papers corresponded to the scope of the review and were included for analysis. The study constitutes all the relevant book chapters, peer-reviewed journal articles, and reviews. The approach of Rashman (2009) was followed for the selection strategy. Figure 1 illustrates the mechanism of retrieval and selection of articles.

(Insert Table II and Figure 1 about here)

\section{Results}

This section recapitulates the diverse definitions of PFMB that various researchers have adopted. It intends to provide the readers with a bird's eye view of the concept of PFMB. The extant theories that have been conceived, tested, or applied during PFMB research are also encapsulated. Further, the review was methodized, and content analyzed in a way that sketches a map of current PFMB literature in the form of yearly publication trends, sample country trends, sample population, PFMB components, trends in research design, the conceptual framework, antecedents, and consequences of PFMB.

\subsection{Definitions}

PFMB has been construed and measured disparately in the extant literature, specifically variegated by the sample. For instance, research focusing on the determinants and outcomes of individuals' PFMB defines it as a set of behavioral components, such as budgeting, cash flow management, consumption, savings, investment, borrowing, or insurance (Joo and Grable, 2000; Dew and Xiao, 2011). On the other hand, studies focusing on the family financial management among couples have defined PFMB as income allocation within the household: pooled income or separate income or household allowance (Pahl, 1989). Similar studies also define PFMB as the division of labor and breadwinning role in a family (Vogler et al., 2006; 
Kulic et al., 2020). The measures used in these studies, in terms of behavioral components, differ significantly by researchers. Therefore, the incongruity in the findings has cropped up. Such inconsistencies make our knowledge and understanding of PFMB blurry.

The concept of PFMB is also closely related to FL (Kebede et al., 2015). Classical economists implicitly assume that increases in financial knowledge will result in changes in financial management behaviors (Hilgert et al., 2003). However, empirical shreds of evidence pertinent to the impact of FL on financial behaviors are not irrefutable (Xu and Zia, 2012). Thus, it is necessary to understand the behavioral biases that go against the standard economic theory, moving individuals from rational agents to behavioral agents. Table III has been formed to provide the readers with a glimpse of the diverse definitions of PFMB figured out in the extant literature.

\section{(Insert Table III about here)}

\subsection{Extant Theories Employed}

Plenty of theories have been impelled by the authors to predicate their research on PFMB and to set the background for empirical investigations on factors influencing it. Figure 2 shows the evolution of theories related to PFMB from the period 1930-2010. The concept of PFMB is primarily based on behavioral finance theories, out of which Theory of Planned Behavior (TPB) is the most prominent one (Ajzen, 1991). It recognizes the psychological aspects by examining the attitude-behavior relationship. According to the TPB, amid other factors, attitude frames behavior, which in turn shapes behavior. The TPB has been endorsed in a wide range of behaviors, including saving (Copur and Gutter, 2019). Another theory, which is the Theory of Reasoned Action (TRA), proposes that the behavior is regulated by an individual's intent to perform the behavior. Intention is determined by attitudes and subjective norms (Ajzen and Fishbein, 1975).

Another intermittent theory that has been ingeniously applied in the literature is the Theory of Consumer Socialization (TCS), especially concerning youth financial learning (Shim et al., $2009,2010)$. The TCS provides a framework that delineates the financial socialization agents (teachers, parents, peers, and the media) determining an individual's financial behavior (Moschis, 1987). Shim et al. (2010) contemplated two learning modalities: observational learning and formal learning. Social Learning Theory (SLT) highlights observational learning's role in determining financial behavior (Bandura and Walters, 1977). Observational learning is also explained by the Social Cognitive Theory (Bandura, 1989). The theory proposes that observation of others interacts with one's own behavior and one's cognitive process to influence that individual's behavior.

Further, the life cycle hypothesis of savings explains the PFMB by assuming that individuals consume a uniform portion of their income over the life cycle and are not born with inheritance and die without leaving a bequest (Ando and Modigliani, 1963). Thus, individuals at a young age tend to borrow to acquire education. Individuals in their middle age are expected to pay off debts and save for the future. During their retirement years, they are expected to utilize their accumulated assets. However, many retired people still save and intend to transfer their accumulated wealth to the next generation. A study by Mugenda et al. (1990) focused on the Family Resource Management System Model proposed by Deacon and Firebaugh (1988). The Family Resource Management System Model was conceptualized as composed of inputs, throughputs, and outputs. The input component of the family managerial system was composed of material resources (income, savings, and net worth) and human resources (education and knowledge). The throughput component was comprised of transformation processes which included money management practices and communication. The output component was characterized by satisfaction with financial status and quality of life. 
A plethora of other theories forms the ground for various antecedents (discussed later in the paper) of PFMB. Table IV features the theories that have been applied in the extant literature on PFMB, but in no way is the number exhaustive. Therefore, it aims to present the capsulation of theories (in chronological order) that have been traced from the existing studies.

(Insert Table IV and Figure 2 about here)

\subsection{Trend of publication in time}

Figure 3 illustrates the progression of publications in PFMB research. Although the research on PFMB exists since the 1970s, it is notable that the gigantic emergence of PFMB research can be seen only during the last decade (2011-2020). Personal finance, a topic of consideration from institutional and consumers' viewpoints, is rather a recent trend (Schuchardt et al., 2007). The concept of PFMB can be traced back around two centuries in the name of home economics (Gross et al., 1980), with barely any attention from economists and business faculty predominantly. The setting up of Financial Counseling and Planning (FCP) offers a ground for personal finance researchers to "generate knowledge, publish information, educate professionals, and provide research programs" (Reynolds and Abdel-Ghany, 2001, p.382). Another event that changed the scenario was introducing the phrase "household finance" by Campbell (2006), who emphasized the fusion of this crucial topic into the vast finance area. Also, a scholar from a consumer science background viewed this topic from consumers' perspective and used the term "consumer finance" (Xiao, 2008). Professor Tufano viewed this term from a business perspective (Tufano, 2009). In current years, household finance, family finance, consumer finance, personal finance, and individual finance promote research on this topic (Xiao and Tao, 2020). The increasing interest in PFMB and its significant visibility in the research recently can be attributed to the increasing power of money with the individuals, liberal credit policies, shift from defined benefit to defined contribution plans, and lack of money management skills among the individuals (Lusardi et al., 2010; Xu and Zia, 2012). The global financial crisis of 2008, characterized by high consumer debt and inadequate savings, expressed a "teachable moment" for the society at large and called for a policy focus on efficient conventions in FL and consumer protection (OECD, 2009). The government and financial educators are working hand in hand to increase the awareness of the vitality of PFMB. The continued research pieces of evidence pertinent to discerning personal financial behavior are indeed required.

(Insert Figure 3 about here)

\subsection{Sample country and population}

The analysis reveals that out of the total number of studies under review $(n=160), 144$ studies derived their samples from single countries. Five studies were based on the data collected from multiple countries, and eleven studies are not country-specific (see table V). By "Not countryspecific," the authors mean that the studies are either purely conceptual or review. After further delving into the geographical location of the sample taken into each study $(\mathrm{n}=144)$, it was found that most of the PFMB studies have been conducted in the American region $(n=62)$. However, this finding may partly be because just $47 \%$ of the US adults report maintaining a budget and tracking their expenses (Consumer Financial Literacy Survey, 2020). According to the National Financial Educators Council (NFCC), the average debt of the US college graduating students increased from $\$ 18550$ (in 2004) to $\$ 28950$ (in 2014). Alarmingly, 54\% of Americans say that they have not set aside three months' worth of living expenses in case of an emergency (Yakoboski et al., 2020). Next, the studies took place in the Europe region $(n=26)$ and the Asia region $(n=22)$. The finding also remarks that the research on PFMB is skewed towards developed countries like the US and the UK. Less attention has been paid to the regions like 
Asia, Australia, and Africa. The results recommend a need to study PFMB in developed as well as developing economies as the subject holds importance across the globe.

Upon manually scrutinizing the sample population in the studies (Figure 4), it was discovered that the adult population (irrespective of a particular age group or a population cohort) was used as a sample in most of the studies $(n=52)$. Further, 26 studies were conducted on young adults, including college students. The effect of various factors on young adults' financial practices has been extensively studied as they enter adulthood with bad experience managing their finances (Lusardi et al., 2010). Personal finance is a sub-discipline of household finance (Schuchartdt et al., 2007), and therefore, studies on couples $(\mathrm{n}=20)$ and households are manifold $(n=14)$. On similar grounds, the low-income population is the most vulnerable when it comes to financial management as they have to deal with the scarcity of financial resources. Thus, PFMB studies on a low income are noticeable $(\mathrm{n}=16)$. "No specific sample" means that the studies are either purely conceptual or review and thus do not include any sample. Results reveal that far fewer studies have been performed on women, older adolescents, professionals, and government employees, signaling a research gap.

(Insert Table V and Figure 4 about here)

\subsection{PFMB structure (Contents and measures)}

Each of the components of PFMB is vital for overall financial well-being (Xiao, 2008; Riitsalu and Murakas, 2019). Upon manual segregation of the extant literature on PFMB, it was discerned that different researchers measured PFMB through the inclusion of different components as a financial management behavior scale. This shows a non-consensus on the measurement and a lack of a comprehensive measure of PFMB (Dew and Xiao, 2011). Extending the analysis of studies further exposits that there are too many "conceptualizations" of PFMB. For instance, in couples' or household finances, PFMB is conceptualized as the income organization or money management method among couples (pooled income, independent income, or allowance). Contrarily, in the case of an individual's finances, PFMB manages finances in the multiple domains of savings, investment, credit, insurance, retirement, etc. Another interesting finding is that there are some studies ("Not specific") (n=37) in which the researchers have not specified the specific domain in which the PFMB is assessed. Notably, consumption, asset management, wealth accumulation, mortgage repayment, tax planning, estate planning, fintech, and charitable giving are distinct themes found in the literature. Such an exploration could help researchers and policymakers give an eye view on measures related to PFMB, which are not much paid attention to. It should be noted that the studies might have included more than one PFMB component. Figure 5 exhibits the number of studies published on various themes (contents) of PFMB.

Few validated financial management behavior scales exist in the literature. A snapshot of the most popular existing PFMB scales is shown in Table VI. Most of the scales lack psychometric validation except the one developed by Dew and Xiao (2011) and are based on selective financial management behaviors. The OECD measure includes a thorough instrument for measuring financial behaviours. It has been validated and used in many countries around the world. While the inclusion of all the domains of financial management is important to be included in the scale, the development of generalized sample measure is crucial.

(Insert Figure 5 and Table VI about here)

\subsection{Trends in research designs}

In this section, we manually segregated the studies based on the research method, research design, data collection technique, and data analysis approach (see table VII):

1) empirical studies include research articles that are based on observation, experiments, and measurement of phenomena; 
2) conceptual studies include research articles that comprise of the development of some concept, framework or are theoretical;

3) quantitative studies include research articles that are based on statistical, numerical, or mathematical analysis of survey or secondary data;

4) qualitative studies include research articles that are based on the collection and analysis of non-numerical data through focus groups, interviews, first- hand information, etc.;

5) modeling and analytical methodology - based articles rest only on mathematical derivations or simulated/created datasets.

Of 160 studies, 145 are empirical, six are conceptual, five are literature reviews, three are modeling based and analytical, and one is a mixed study (empirical + conceptual). Of the 145 empirical studies, 121 studies used quantitative research design, 18 studies used qualitative methods, and six were based on a mixed-method approach (both qualitative and quantitative methods). There exists a dearth of conceptual studies on the subject.

Further comprehensive analysis shows that most empirical studies are based on surveys $(n=113)$; just one study was based on archival data. Seven studies were based on laboratory experimentation. As identified in the previous section, research on PFMB is in an emerging phase, and that the majority of the publications have taken place in the last few years. Despite this, the focus is on quantitative empirical research methods compared to qualitative methods. This might result in biased, inconsistent, and ambiguous research findings. More qualitative studies are essential to delve deeply into the subject and identify the insightful determinants of PFMB.

As we classify the articles based on data analysis approaches to identify the most prominent techniques/tools, it was discerned that regression is the most frequently applied technique, and OLS regression is the most popular type of regression used. Apart from regression, SEM has been used by some researchers. SEM is a comprehensive approach based on the confirmatory measurement used to assess the models related to psychological studies (Anderson and Gerbing, 1988). Researchers have also applied correlation widely to analyze the relationships. Other techniques applied include descriptives, ANOVA, Chi-Square test, t-test, factor analysis, discriminant analysis, mathematical models, and MANOVA.

(Insert Table VII about here)

\section{The conceptual framework}

The research done on the subject revolves around the antecedents that are likely to influence PFMB and its consequences, which are either positive, negative, or insignificant. It is an absolute need of the hour to realize the vitality of the concept of PFMB and advance the arguments on its determinants and terminal outcomes. This review proposes an integrated framework that connects various disjointed theoretical fragments. The model (see figure 6) calibrates the peculiar findings and gives a direction to future research.

(Insert Figure 6 about here)

\subsection{Antecedents of PFMB}

Over the past few decades, PFMB has stemmed as a process, which is of paramount concern for an individual. Therefore, it is crucial to know the various expediting factors of PFMB. On an extensive inquiry of the literature, it was identified that myriads of factors impact financial behavior. Such factors are demographic and socio-economic characteristics, psychological and personality factors, social factors, FL, professional financial advice, environmental factors, technological factors, circumstantial factors, cultural factors, and financial experience, among others (Table VIII). 
PFMB can differ between population sub-groups according to marital status, income, occupation, gender, education, and family structure (Perry and Morris, 2005; Grable et al., 2009; Loke 2017a; Sachitra et al., 2019; Bapat, 2020). In comparison to the work done on demographics and socio-economic factors, research on psychological factors underlying personal financial planning behavior is in an elementary stage (Joo and Grable, 2004; Xiao and Porto, 2019). Based on the existing body of literature, various psychological factors have been accounted for. Behavioral finance theories have acknowledged psychological disposition in determining PFMB (Copur and Gutter, 2019). In the last decade, various researchers have investigated the relationship between financial socialization and financial behavior (Shim et al., 2009; Bamforth et al., 2018; Antoni et al., 2019). Parents are essential socialization agents in how children learn about money and develop financial management behavior, often incidentally (by observation and participation) and through lessons delivered intentionally by parents (Moschis, 1987).

Another most critical factor of PFMB is FL. Academic work has concluded that FL is an antecedent to various healthy financial behaviors such as saving (Pak and Chatterjee, 2016), borrowing (Allgood and Walstad, 2013), investment (Hastings and Mitchell, 2020), and overall personal financial planning (Boon et al., 2011). As with many areas of personal finance, there is little appreciation of precisely how individuals rearrange their portfolios around and during major life events. These are often difficult to plan (West and Worthington, 2019), such as loss of a job, major disability, or long-term illness, divorce/remarriage, starting a family or sudden inheritance. Regarding technological factors, information about financial products and services digitally may also influence financial behavior (Bapat, 2019). Financial advisors are a critical source for improving financial behaviors and well-being among clients and communities (Moreland, 2018).

(Insert Table VIII about here)

\subsubsection{Indirect effects (Mediators and moderators)}

In figure 6 of the study, the potent insights from the literature review have been assembled to provide the readers with an outline of the variables and relationships encompassing PFMB.

The direct influence of a determinant on behavior is reported in table VIII, but many factors indirectly influence PFMB. Most of the allied literature on psychology proposes that the relationship between attitude and behavior might be influenced by a third variable, FL (Eagly and Chaiken, 1993). Barbic et al. (2019) found that FL moderates (interaction effect) the relationship between financial attitude and behavior $(\beta=-0.0850, p<0.01)$. The attitudebehavior relationship weakens as the FL increases. Moreover, in the study conducted by Topa et al. (2018), Need for Cognitive Closure (NCC) is found to moderate the relationship between Investment Literacy and financial management behavior where the effect was high at the high level of NCC and weak at a low level of NCC. NCC is a socio-psychological term that refers to an individual's inclination for a fixed answer to a question rather than ambiguity and confusion (Webster and Kruglanski, 1994). The differences in NCC may influence an individual's capacity to process information and their decision-making.

Further, upon exploring cross-cultural conceptualization of human behavior, a negative interaction was found between Korean and financial knowledge $(p=.055)$ on financial management behavior (Grable et al., 2009). Although greater than $p<.05$ but less than $p<.10$, it indicates a meaningful relationship. In a similar study, it was also found that the culture does not exert an influence (no significant interactions) on the relationship of Locus of Control (LOC) and income with financial behavior. LOC relates to the magnitude to which an individual's success or failure results from their actions (Perry and Morris, 2005). Another variable, excessive lifestyle, which is related to overspending habits, moderates the relationship between PFMB and youth bankruptcy awareness (Azmi et al., 2019) in such a way that the 
relationship is more substantial in case of a lower excessive lifestyle $(\beta=0.109, p<0.05)$. Bapat (2020) found that financial risk tolerance moderates the relationship between financial knowledge, financial attitude, internal LOC, and financial management behavior. Another psychological construct of perceived control is to moderate the budgeting intention (Kidwell and Turrisi, 2004). Individual self-regulation would also moderate the relationship between differences in future orientation and investment in a high-risk mutual fund, $F(1,83)=10.03$, $p<.01$ (Howlett et al., 2008). This means that high future-oriented individuals had a less favorable attitude towards risky investment when self-regulation was high. Materialism is defined as "the importance ascribed to the ownership and acquisition of material goods in achieving major life goals or desired states" (Richins, 2004, p.210). Higher materialism results in higher money management-related stress, but time perspective is found to moderate this relationship (Ponchio et al., 2019).

Besides moderating effects, mediation effects have also been hypothesized in the literature. In the study by Bapat (2020), financial attitude fully mediates the relationship between financial knowledge and financial management behavior $(\beta=0.372,0.533, p<0.05)$. Barbic et al. (2019) also affirm a significant indirect relationship between FL and financial management behavior through financial attitude mediation. This finding focuses on the need to incorporate psychological facets to transform financial knowledge into financial behavior through financial attitude. A study by Ho and Lee (2020) has found that students who accredit power distance still exhibit positive financial behavior if they have a positive financial attitude as a mediator in the relationship $(\beta=0.12, p<0.01)$. Power distance is a cultural disposition in which less powerful members of the society accept that power is unevenly distributed (Hofstede, 2001). Higher power distance is likely to result in negative financial behavior (Ho and Lee, 2020). Another psychological construct that completely mediates the relationship between procrastination and financial behavior is financial self-efficacy $(\beta=-0.262, p<0.05)$ (GamstKlaussen et al., 2019). Therefore, financial self-efficacy, which means an individual's abilities to achieve a financial goal, is critical to financial health. The relationship between investment literacy and financial management behavior is also mediated by investment advice use (Topa et al., 2018). Studies by Perry and Morris (2005) and Grable et al. (2009) reveal that LOC mediates the relationship between FL and financial management behavior. The indirect effect of subjective financial knowledge also exists in the relationship between self-esteem and financial behavior (Tang and Baker, 2016).

\subsection{Consequences of PFMB}

Table IX furnishes a detailed content analysis of the consequences of PFMB as explored in the literature. It is noteworthy that the researchers' focus in the domain has primarily been on figuring out the antecedents of PFMB. Most of the empirical investigations have considered PFMB as an outcome, and the resultant variable outcomes of such behavior have not received much attention. The existing work exposits that financial behavior can influence financial satisfaction (Mugenda et al., 1990; Gunay et al., 2015). To examine the causal relationships of factors that influence money management tasks, Mugenda et al. (1990) remarked upon the finding that "net worth, savings, debt payments and lack of financial difficulties" are the main predictors of financial satisfaction. Joo and Grable (2004) identified that financial behaviors are closely associated with an individual's financial stress levels. Good financial behaviors are also the predictors of happiness in life through relationship satisfaction mediation (Spuhlera and Dew, 2019). The concept of FL, financial capability, and PFMB are greatly connected (Xiao et al., 2014). Financial capability is having financial knowledge and performing financial behaviors through financial access (Taylor, 2011). Financial capability through desirable financial behaviors results in financial satisfaction (Xiao et al., 2014; Xiao and O'Neill, 2018b). 
Borrowing and insurance behaviors positively influence relationship quality between partners and their subjective financial well-being (Baryła-Matejczuk et al., 2020). These dimensions are closely connected to the psychological aspects of satisfaction of routine basic needs. The evidence of such life gains can help service providers motivate clients to perform better financial behaviors. Such behaviors are also the predictors of making defaults in payments and saving for the future (Miotto and parente, 2015).

(Insert Table IX about here)

\section{Agenda for future research}

Although emerging research on PFMB encompasses sizable contributions in the late years, the literature's coalescence has brought to light profound gaps in understanding of the subject. Such gaps build the momentum for future theory development and research on PFMB. Table X sums up the recommended agenda for different propositions in the form of research questions on variables and their linkages, followed by empirical advancements on methods and measures.

\subsection{Theoretical development}

This section describes how various theories can be applied to PFMB and how future research can be developed to better comprehend financial behavior, which provides useful information for policymakers. Due to its interdisciplinary nature, the profession of personal finance has various theories to choose from (Schuchardt et al., 2007). The collective scholarship on the behavioral complexities of PFMB happens to come from several interdisciplinary fields, such as behavioral economics, economic psychology, behavioral finance, sociology, family studies, technology, couples' finances, and consumer research. Future research should be focussed on how theoretical approaches can be used in multiple disciplines can inform PFMB.

The traditional life-cycle hypothesis assumes that individuals are well-informed and behave rationally by smoothing consumption and saving over their life-cycle (Ando and Modigliani, 1963). Notwithstanding, our analysis acknowledges that individuals confront many behavioral biases that are not predicted by the standard theory. Such interplay of psychological attributes must be backed up by the various theories specific to the personal finance domain. In addition to this, the majority of the studies have focused on attitudinal, normative, controlling, and experiential perceptions about financial decisions (Lee and Hanna, 2014; Barbic et al., 2019). Triandis (1994) emphasizes the cultural dimensions that are often overlooked by others in the field. There is a need to develop socio-psychological theories to support behavioral biases due to culture and other social factors. The TTM assumes that self-efficacy plays a significant role in behavior change (Prochaska and DiClemente, 1982). Hence, individuals who doubt their capabilities to handle finances are more likely to reduce effort, making them more susceptible to unhealthy financial behaviors like impulse purchases (Gamst-Klaussen et al., 2019). Relevant theories must be used to identify the stage at which people are willing and able to alter their behavior.

Further, as our review suggests, the TPB and the TTM have been tested on certain financial behaviors (Xiao et al., 2004a; Xiao et al., 2004b) and certain groups of population (Kidwell and Turrisi, 2004; Copur and Gutter, 2019; Bapat, 2020). Further, FL leads to desirable financial behaviors (Hilgert et al., 2003; Lusardi and Mitchell, 2007), but there is some evidence where financial education has been found to have weaker or insignificant effects on financial behaviors (Fernandes et al., 2014). It is of great interest for financial educators to know the influence of financial education on behavior change. While the work that financial education is expected to do has been identified, the role of theory in aiding educators to perform such a role has still not been established. The scholarly work to date creates a promising ground for exploring financial education's theoretical fragments, financial behavior, and life satisfaction. 
TCS has been applied to determine the influence of parent-child financial socialization processes on adolescents' or young adults' money management practices (Shim et al., 2009). The majority of the studies have focused on parental influence in general rather than specific socialization practices (Sundarasen and Rahman, 2017; Fulk and White, 2018). Such specific domains can be identified through specific realms in social learning theories (Xiao et al., 2011). Other socialization agents, such as peers and media, need further exploration.

The behavior theories reviewed in this paper have been applied in various scientific research studies. Researchers in consumer finance could make use of this line of research to inform financial educators and consumers. Future research should also determine how financial education, financial behavior, and quality of life are related.

\subsection{Empirical advancement}

6.2.1 Antecedents of PFMB

The empirical work done on the antecedents of PFMB is considerable. The research stream stressed the importance of psychological factors in better comprehending the positive or negative financial outcomes, either directly or indirectly (Hoffmann and Mcnair, 2019). Given the established relationships, it is critical to understand the processes through which such factors differentially relate to a set of financial outcomes, and for that, theoretical synthesis is fundamental. For instance, saving is a financial decision made within a social context, is based on life-cycle stages and the psychological attributes of the savers (Copur and Gutter, 2019). However, there is a limited research using a comprehensive method to understand the multiple factors that affect financial behavior. PFMB is undoubtedly one of the most prolific research areas in personal finance, yet Copur and Gutter (2019) and Bapat (2020) state that not much is known about the determinants of PFMB.

Notwithstanding the preponderance of studies on PFMB determinants, there are still some issues that constitute entry points for new research in the area. First, there seems different results on the same constructs (negative or positive or insignificant relationships) relating to the impact of factors on various financial behaviors such as income level (Perry and Morris, 2005 vs. Grable et al., 2009), education (Gorniak, 1999 vs. Loke, 2017a), household size (Mugenda et al., 1990 vs. Borda and Kowalczyk-Rólczyńska, 2016), perceived Control/selfControl (Kidwell and Turrisi, 2004 vs. Zulfaris et al., 2020), LOC (Bapat, 2020 vs. Grable et al., 2009), personality traits (Xu et al., 2015 vs. Harrison and Chudry, 2011), financial education (Fulk and White, 2018 vs. Fernandes et al., 2014), and objective FL (Bapat, 2019 vs. Pak and Chatterjee, 2016). Such contradictions need re-investigations. Further, the tested effects of demographics on financial outcomes are not unusual, but the research has discounted how demographics indirectly affect financial outcomes via financial socialization processes (Shim et al., 2009, 2010). The tenets of consumer socialization theory could advance explanations for individual differences in FL and resulting financial behavior (Moschis, 1987, Gudmunson and Danes, 2011). Additional research on hierarchical financial behavior needs to be conducted with other financial behavior such as saving, investing, borrowing, and retirement (Xiao and O'Neill, 2018a). More research is required to examine the relationship between fintech and various consumer financial topics since fintech has changed the overall ecological environment of consumer finance in many ways (Xiao and Tao, 2020). Lastly, as with many areas of personal finance, there is little appreciation of precisely how individuals rearrange their portfolios around and during major life events (West and Worthington, 2019), such as loss of job, major disability or long-term illness, divorce/remarriage, starting a family or sudden inheritance.

Future researchers can advance more work on: socio-demographic and economic factors such as occupation, household size, homeownership, family structure, generational complexity, and gender disparities within couples; psychological factors such as self- 
regulation, negative emotions, distrust, cognitive style, motivation, perceived ability, planning horizon, financial optimism, self-other orientation, framing effect, emotional intelligence, and procrastination; social factors such as financial socialization through peers, colleagues, and media; environmental factors; technological factors; financial experience; financial resources and financial vulnerability. It is essential to know how financial socialization and education vary by gender, life stage, race, socio-economic status, education, and ethnicity (Schuchardt et al., 2009). Riitsalu and Murakas (2019) findings show that objective financial knowledge is less related to financial well-being than subjective financial knowledge and financial behavior. Additional research is required to explore antecedents of financial knowledge as such skills are pivotal for good financial behavior (Grable et al., 2009). Future studies need to be careful when getting insights from the perspective of personal, behavioral, and environmental factors and may consider including specific individual behaviors (Bapat, 2019).

\subsubsection{Mediators}

The pathways between various factors and proper financial management behavior are major research questions that need to be addressed. Financial attitude mediates the relationship between FL and financial behavior (Barbic et al., 2019; Bapat, 2020). First, the mediating relationship of financial attitude between financial socialization and financial behavior needs to be tested as financial socialization influences FL (shim et al., 2010). Future research should also consider additional psychological factors as mediators between demographics and financial behavior. LOC plays a mediating role in the relationship between financial knowledge and financial behavior (Perry and Morris, 2005), but such an effect may differ for different groups of people. The interplay among various psychological factors is also an exciting research area as they are interrelated (Bapat, 2020). Apart from gender and power in couples' finances (Pepin, 2019; Cineli, 2020), the interactions of social categorizations such as race/ethnicity or socioeconomic status may be useful to understand couples' financial systems and relational outcomes.

\subsubsection{Moderators}

There are inconsistent results regarding the moderating effects of FL on the relationship between financial attitude and financial behavior. In general, the relationship tends to be firm with high FL and weak with low FL (Eagly and Chaiken, 1993). Nevertheless, in some cases, the moderating effect is negative, i.e., when FL is high, the attitude-behavior relationship weakens (Barbic et al., 2019). Such findings propel deeper inquiry. Research reveals that financial advice influences financial management behavior (Topa et al., 2018; Moreland, 2018). The interaction effects of such advice with FL and financial behavior would be an exciting research proposition. The moderating role of culture on FL and behavior has been tested in Korea (Grable et al., 2009). Such a relationship needs to be explored in other countries as well. The moderating role of additional psychological factors in changing the relationship between demographics, FL, social factors, and financial behavior needs to be incorporated in future studies. Findings suggest that electronic banking positively affects financial behavior (Bapat, 2019). Information about financial products and services digitally may also influence financial behavior. There is also a relationship between FL and fintech. Low FL leads to low adoption of fintech (Morgan and Trinh, 2019). However, how fintech may influence FL is another compelling future research area.

\subsubsection{Consequences of PFMB}

It is apparent from Figure 6 that a major chunk of PFMB literature has targeted antecedents, and research on its consequences is minuscule. Further exploration is encouraged on the psychological and sociological aspects of financial attitudes and behaviors and their 
relationship with financial satisfaction (Xiao et al., 2014; Spuhlera and Dew, 2019). Such studies will help consumer and family economists better understand the motives, drives, and effects that determine individuals' quality of life. Not many studies have empirically confirmed that the amount of money that one makes is less important than the money that one spends (Shim et al., 2009). There has been a continuous debate on the linear relationship between income and happiness (an indicator of subjective well-being) in longitudinal data (Stevenson and Wolfers, 2013). Notably, PFMB and financial access are essential for overall financial well-being yet have not been much explored (Birkenmaier and $\mathrm{Fu}, 2019$ ). Better financial behavior may result in better financial access and better financial status (Gunay et al., 2015). Again, there is a causality issue implying that financial access succeeds financial behavior and vice-versa (Xiao et al., 2010). In addition to this, other terminal outcomes such as financial resilience in times of emergencies warrant equal attention in the research (Lusardi et al., 2020). According to Salignac et al. (2019, p. 5), "Financial resilience is an individual's ability to access and draw on internal capabilities and appropriate, acceptable and accessible external resources and supports in times of financial adversity." Future research should explore how the economic shocks transform exposure to risk and risk management preferences both at the individual and household levels (Schuchardt et al., 2009).

\subsection{Methodological Expansion}

\subsubsection{PFMB measurement}

Following the gap of a very few validated financial management behavior scales in the research, there is a need for the researchers to establish financial behaviors inventory covering all areas of behaviors (Dew and Xiao, 2011). Unfortunately, most of the existing studies measure financial behaviors as per their convenience and lack a comprehensive composition. Such a reliable and validated inventory would be advantageous for financial educators and policymakers when evaluating financial education programs' influence on financial behavior, financial satisfaction, and quality of life. To comment on the robustness of existing measures, such scales must be scrutinized and used at different places and situations and on various samples. This process may contribute to the maturity of the construct and its measurement. Further research should also focus on developing scales that might reflect desirable financial management behaviors, are relevant, and based on respondents' age or life situation. For instance, a retired person might not opt for "long-term savings." Thus, PFMB is an umbrella term that incorporates multiple behaviors related to individuals, households, and consumers (Xiao and Tao, 2020). Application of other methods such as Factor analysis is also desirable.

\subsubsection{Methods}

Extant literature shows that quantitative methods have been predominantly applied to understand PFMB so far. Upon scrutinizing the sample countries in our review, we find that the PFMB research should be focused equally on developing economies due to changing the financial markets landscape (Xu and Zia, 2012). Further, our more in-depth inquiry into the various research methods applied in the extant research spotlights eminent gaps in the methodology and possible contributions to enriching knowledge in this area. Future research should be extended to incorporate more conceptual papers focusing on the better conceptualization of the PFMB construct. There is a dearth of studies collecting data from secondary sources and the studies that are qualitative. Theoretical roots of PFMB point out that consumers who are high on money ethics, risk aversive, and future-oriented are more likely to show positive financial behavior. Qualitative research is needed to understand such complex frameworks grounded in psychology. Most of the studies are survey-based (Boon et al., 2011), and case-study and interview-based research are lacking. The use of an alternative qualitative approach over quantitative methods may help gain a holistic understanding of the influence 
exerted by various factors on PFMB and how, in turn, PFMB influences other outcomes. Qualitative research (e.g., interviews and focus groups) would be useful to dig in the role of attitudes and intentions. Additional methodologies could be applied to examine the factors involved into the field of family financial issues. The researchers have used various data analysis approaches, but regression has been most commonly used by most of them. SEM should be applied in future studies. The mixed method of empirical research (both quantitative and qualitative) has not been often used in PFMB research. Mixed methods are useful in discerning contradictory findings between quantitative and qualitative studies and a better understanding participants' experiences. The mixed methodology can improve study robustness since the usage of the quantitative techniques improves the validity of the research. Future research can include mixed methods, as well. Besides, it is suggested to the researchers to critically compare their findings with varied outcomes of previous results while examining the relationship between various factors and PFMB, positive or negative or insignificant. Moreover, in order to understand the influence of attitudes and socialization process over time and gain better insights on cause-and-effect relationships, future studies using longitudinal data sets are needed (Copur and Gutter, 2019).

(Insert Table $\mathrm{X}$ about here)

\section{Implications}

The results of the study indicate that the determinants and outcomes of short-term and longterm personal financial planning are manifold. These findings have several implications for financial planners who play a significant role in promoting consumer financial well-being. Improving responsible financial management behavior has been a challenge for financial counselors. This study contributes to the academic platform by providing the fundamentals of PFMB under one umbrella. In addition to making academic contributions, the findings can be utilized by business professionals and financial service providers to understand the consumers' PFMB. It will empower them to develop financial strategies and appropriate financial products and services to meet consumers' life goals while creating wealth and money for them and giving potential business growth to the professionals. Such a study can be important to the young working professionals who find themselves at the crossroads while making economic decisions. Understanding how money and its literacy influence well-being will help financial advisors to guide individuals in gravitating towards prudent economic decision-making. There is a prompt need to develop an appropriate scale of PFMB. A strong comprehensive measure could assist researchers and practitioners in various domains. Appropriate measurement of financial behavior may have implications on physical health, mental health, and life satisfaction (Xiao et al., 2009).

Further, financial education is one of the educators' primary agendas, social groups, policymakers, businesses, and the government (Fernandes et al., 2014). Financially stable households and individuals are better able to achieve their well-being as well as foster economic growth. Financial educators' goal is not only imparting financial knowledge to the students but also modifying their financial behavior for ultimate financial success (Hilgert et al., 2003). To develop financial, educational programs focusing on behavioral change, personal/consumer finance researchers need to understand better how such behaviors are shaped and modified into desirable actions.

In the wake of the global crisis of 2008, policymakers have shown concern about financial illiteracy and how people handle their finances. The COVID-19 has undeniably led to an aberrant health crisis and has sparked a global financial crisis, which is even worse than the 2008 financial crisis. The novel virus's financial repercussions could be long-lived and develop a long haul in the form of fragilities in the structure. Having emergency funds, investing wisely, conservative borrowing, insurance coverage, and setting financial goals are some of the life- 
saving skills that can provide financial resilience in a crisis. The present study can help policymakers, financial educators, consumers, and researchers unbundle the strategies to challenge yet another crisis and take away lessons for future action courses.

\section{Conclusion}

The panorama of financial decisions confronted during the life course is considerably astounding (Yakoboski et al., 2020). Individuals need to make a myriad of decisions relating to their finance, such as consumption, cash flow, saving, investment, borrowing, retirement, tax planning, estate planning, and insurance. However, all financial decisions are intrinsically intertwined and often involve a trade-off. How efficiently individuals manoeuvre personal financial decisions rests partly on their financial knowledge and money management skills (Lusardi and Mitchell, 2007) and partly on behavioral, cultural, demographic, sociological, economic, and technological factors. Therefore, understanding the evolution of the literature on personal financial decision-making over time counts significantly at both levels, individual and society. To this end, this review was undertaken to gauge the antecedents and consequences of PFMB primarily across the depth and breadth of the subject. The research trends were also examined to deliver the most comprehensive retrospective on the dynamic nuances of PFMB. Like other studies, this review is not clear of limitations. Although we have attempted to ensure that the terms used in the search represent the broad scope of the area, there might be a few studies missing because of the absence of any related term in the search criteria. Secondly, although the search has taken cognizance of maximal studies on the subject, searching other databases can fetch added results. Further, it focuses on the studies published in the English language only, without considering the issues in other languages, which may have comprehended diverse views and arguments about PFMB. Abiding by the review's scope, the research trends have been analyzed only for 160 studies about the antecedents and the consequences of PFMB. Nonetheless, PFMB is most critical in an average individual's life yet underserved discipline from an academic viewpoint.

\section{References}

Ajzen, I. (1991), "The theory of planned behavior", Organizational behavior and human decision processes, Vol. 50 No. 2, pp. 179-211.

Ajzen, I. and Fishbein, M. (1973), "Attitudinal and normative variables as predictors of specific behavior", Journal of personality and Social Psychology, Vol. 27 No. 1, pp. 1-41

Allgood, S. and Walstad, W. (2013), "Financial literacy and credit card behaviors: A cross-sectional analysis by age", Numeracy, Vol. 6 No. 2, pp. 1-26.

Altfest, L. (2004), "Personal Financial Planning: Origins, Developments and a Plan for Future Direction", The American Economist, Vol. 48 No. 2, pp. 53-60.

Anderson, J.C. and Gerbing, D.W. (1988), "Structural equation modeling in practice: A review and recommended two-step approach", Psychological bulletin, Vol. 103 No. 3, p.411.

Ando, A. and Modigliani, F. (1963), "The 'life cycle' hypothesis of saving: Aggregate implications and tests", The American economic review, Vol. 53 Vol. 1, pp. 55-84.

Antoni, D.Z., Rootman, C. and Struwig, F. (2019), "The Influence Of Parental Financial Socialisation Techniques On Student Financial Behaviour", International Journal of Economics and Finance Studies, Vol. 11 No. 2, pp. 72-88.

Antonides, G., Manon de Groot, I. and Fred van Raaij, W. (2011), "Mental budgeting and the management of household finance", Journal of Economic Psychology, Vol. 32 No. 4, pp. 546555. 
Archuleta, K.L. (2008), The impact of dyadic processes and financial management roles on farm couples (Doctoral dissertation, Kansas State University).

Arifin, A.Z. (2017), "The Influence of Financial Knowledge, Control and Income on Individual Financial Behavior”, European Research Studies Journal, Vol. XX No. 3A, pp. 635-648.

Asandimitra, N. and Kautsar, A. (2020), "The Influence of Financial Information, Financial Self Efficacy, And Emotional Intelligence To Financial Management Behavior Of Female Lecturer", Humanities \& Social Sciences Reviews, Vol. 7 No. 6, pp. 1112-1124.

Atkinson, A. and F. Messy. (2012), "Measuring Financial Literacy: Results of the OECD / International Network on Financial Education (INFE) Pilot Study", OECD Working Papers on Finance, Insurance and Private Pensions, No. 15, OECD Publishing, Paris.

Azmi, A.N., Samah, I.H.A., Rashid, I.M.A., Shamsuddin, A.S. and Harith, M. (2019), "Personal Financial Management And Youth Bankruptcy Awareness: Moderating Effect Of Excessive Lifestyle", International Journal of Scientific and Technology Research, Vol. 8 No. 12, p. 3.

Bailey, J.J. and Kinerson, C. (2005), "Regret avoidance and risk tolerance", Journal of Financial Counseling and Planning, Vol. 16 No. 1, p.23.

Bamforth, J., Jebarajakirthy, C. and Geursen, G. (2018), “Understanding undergraduates' money management behaviour: a study beyond financial literacy", International Journal of Bank Marketing, Vol. 36 No. 7, pp. 1285-1310.

Bandura, A. (1977), "Self-efficacy: toward a unifying theory of behavioral change", Psychological Review, Vol. 84 No. 2, pp. 191-215.

Bandura, A. (1989), "Social cognitive theory", Vasta, R. (Ed.), Annals of child development JAI Press, Greenwich, pp. 1-60.

Bandura, A. and Walters, R.H. (1977), Social learning theory, Englewood Cliffs, NJ: Prentice-hall, New York, NY.

Bapat, D. (2019), "Exploring Antecedents to Financial Management Behavior for Young Adults", Journal of Financial Counseling and Planning, Vol. 30 No. 1, pp. 44-55.

Bapat, D. (2020), "Antecedents to responsible financial management behavior among young adults: moderating role of financial risk tolerance", International Journal of Bank Marketing, Vol. 38 No. 5, pp. 1177-1194.

Barbić, D., Lučić, A. and Chen, J.M. (2019), "Measuring responsible financial consumption behaviour”, International Journal of Consumer Studies, Vol. 43 No. 1, pp. 102-112.

Baryła-Matejczuk, M., Skvarciany, V., Cwynar, A., Poleszak, W. and Cwynar, W. (2020), "Link between Financial Management Behaviours and Quality of Relationship and Overall Life Satisfaction among Married and Cohabiting Couples: Insights from Application of Artificial Neural Networks", International Journal of Environmental Research and Public Health, Vol. 17 No. 4, p. 1190.

Bharucha, J. (2018), "Couples and breadwinning in low-income dual-earner households in India", International Journal of Sustainable Society, Vol. 10 No. 1, p. 62.

Białowolski, P. (2019), "Economic sentiment as a driver for household financial behavior", Journal of Behavioral and Experimental Economics, Vol. 80 No. 2019, pp. 59-66.

Birkenmaier, J. and Fu, Q.J. (2019), "Does Consumer Financial Management Behavior Relate to Their Financial Access?", Journal of Consumer Policy, Vol. 42 No. 3, pp. 333-348.

Boon, T.H., Yee, H.S. and Ting, H.W. (2011), "Financial literacy and personal financial planning in Klang Valley Malaysia", International Journal of Economics and Management, Vol. 5 No. 1, pp. 149-168.

Borda, M. and Rólczyńska, P.K. (2016), "Impact of demographic factors on household financial decisions - evidence from Poland", International Journal of Risk Assessment and Management, Vol. 19 No. 1/2, p. 106. 
Calvet, L.E., Campbell, J.Y. and Sodini, P. (2007), "Down or out: Assessing the welfare costs of household investment mistakes", Journal of Political Economy, Vol. 115 No. 5, pp. 707-747.

Campbell, J.Y. (2006), "Household Finance", The Journal of Finance, Vol. 61 No. 4, pp. 15531604.

Chandra, A., Sanningammanavara, K. and Nandini, A.S. (2017), "Does individual heterogeneity shape retail investor behaviour?", International Journal of Social Economics, Vol. 44 No. 5, pp. 578-593.

Cho, S.H., Gutter, M., Kim, J. and Mauldin, T. (2012), "The Effect of Socialization and Information Source on Financial Management Behaviors among Low- and Moderate-Income Adults: Socialization And Information Source", Family and Consumer Sciences Research Journal, Vol. 40 No. 4, pp. 417-430.

Cho, S.H., Mountain, T.P., Porto, N., Kiss, D.E., Gutter, M.S. and Griesdorn, T. (2016), "Experimental Design to Understand the Student Loan Decision: A Methodological Note", Family and Consumer Sciences Research Journal, Vol. 45 No. 1, pp. 65-76.

Çineli, B. (2020), "Money Management and Gender Equality: An Analysis Of Dual earner Couples in Western Europe", Family Relations, Vol. 69 No. 4, pp. 803-819.

Clearwater, E. and Harvey, C.D.H. (1988), "Correlates of marital satisfaction in a Manitoba low income sample", Journal of Consumer Studies and Home Economics, Vol. 12 No. 2, pp. 183197.

Copur, Z. and Gutter, M.S. (2019), "Economic, Sociological, and Psychological Factors of the Saving Behavior: Turkey Case", Journal of Family and Economic Issues, Vol. 40 No. 2, pp. 305-322.

Daud, S.N.M., Marzuki, A., Ahmad, N. and Kefeli, Z. (2019), "Financial vulnerability and its determinants: Survey evidence from Malaysian households", Emerging Markets Finance and Trade, Vol. 55 No. 9, pp. 1991-2003.

Deacon, R.E. and Firebaugh, F.M. (1988), Family resource management: Principles and applications, Allyn \& Bacon, Boston, the US.

Dew, J., Barham, C. and Hill, E.J. (2020), "The Longitudinal Associations of Sound Financial Management Behaviors and Marital Quality", Journal of Family and Economic Issues, p. 112.

Dew, J. and Xiao, J.J. (2011), "The financial management behavior scale: Development and validation", Journal of Financial Counseling and Planning, Vol. 22 No. 1, p.43.

Doda, S. (2014), "Personal finance management among gender", Mediterranean Journal of Social Sciences, Vol. 5 No. 3, p.170.

Dolan, P., Elliott, A., Metcalfe, R. and Vlaev, I. (2012), "Influencing financial behavior: From changing minds to changing contexts", Journal of Behavioral Finance, Vol. 13 No. 2, pp.126142.

Eagly, A.H. and Chaiken, S. (1993), The psychology of attitudes, Harcourt brace Jovanovich college publishers, California, the US.

Eberhardt, W., Bruine de Bruin, W. and Strough, J. (2019), "Age differences in financial decision making: The benefits of more experience and less negative emotions", Journal of Behavioral Decision Making, Vol. 32 No. 1, pp. 79-93.

Estelami, H. (2014), "An ethnographic study of consumer financial sophistication", Journal of Consumer Behaviour, Vol. 13 No. 5, pp. 328-341.

Fama, E.F. (1970), "Efficient capital markets: a review of theory and empirical work", Journal of Finance, Vol. 25 No. 2, pp. 383-417.

Farrell, L., Fry, T.R. and Risse, L. (2016), "The significance of financial self-efficacy in explaining women's personal finance behaviour”, Journal of Economic Psychology, Vol. 54 No. 2016, pp. 85-99. 
Feng, X., Lu, B., Song, X. and Ma, S. (2019), "Financial literacy and household finances: A Bayesian two-part latent variable modeling approach", Journal of Empirical Finance, Vol. 51 No. 2019, pp. 119-137.

Fernandes, D., Lynch, J.G. and Netemeyer, R.G. (2014), "Financial Literacy, Financial Education, and Downstream Financial Behaviors", Management Science, Vol. 60 No. 8, pp. 1861-1883.

Fishbein, M. and Ajzen, I. (1975), Belief, Attitude, Intention, and behavior: An introduction to theory and research, Reading, MA: Addison-Wesley, Boston, the US.

Fitzsimmons, V. S., Hira, T. K., Bauer, J. W., and Hafstrom, J. L. (1993), "Financial management: Development of scales", Journal of Family and Economic Issues, Vol. 14, pp. 257-274.

Frijns, B., Gilbert, A. and Tourani-Rad, A. (2014), "Learning by doing: the role of financial experience in financial literacy", Journal of Public Policy, Vol. 34 No. 1, pp. 123-154.

Fulk, M. and White, K.J. (2018), "Exploring racial differences in financial socialization and related financial behaviors among Ohio college students", Cogent Social Sciences, Vol. 4 No. 1, p.1514681.

Gamst-Klaussen, T., Steel, P. and Svartdal, F. (2019), "Procrastination and Personal Finances: Exploring the Roles of Planning and Financial Self-Efficacy", Frontiers in Psychology, Vol. 10 , p. 775.

Garðarsdóttir, R.B. and Dittmar, H. (2012), “The relationship of materialism to debt and financial well-being: The case of Iceland's perceived prosperity", Journal of Economic Psychology, Vol. 33 No. 3, pp. 471-481.

Gerrans, P. and Heaney, R. (2019), "The impact of undergraduate personal finance education on individual financial literacy, attitudes and intentions", Accounting \& Finance, Vol. 59 No. 1, pp. 177-217.

Godwin, D.D. and Carroll, D.D. (1986), "Financial management attitudes and behaviour of husbands and wives", Journal of Consumer Studies and Home Economics, Vol. 10 No. 1, pp. 77-96.

Górniak, J. (1999), "Attitudes towards money and dealing with money: Selected results of the research in Poland", Innovation: The European Journal of Social Science Research, Vol. 12 No. 4, pp. 633-645.

Goyal, K. and Kumar, S. (2021), "Financial literacy: A systematic review and bibliometric analysis", International Journal of Consumer Studies, Vol. 45, Issue 1, pp. 80-105. https://doi.org/10.1111/ijcs.12605

Grable, J.E. (2000), "Financial risk tolerance and additional factors that affect risk taking in everyday money matters", Journal of Business and Psychology, Vol. 14 No. 4, pp. 625-630.

Grable, J.E., Archuleta, K.L., Ford, M.R., Kruger, M., Gale, J. and Goetz, J. (2020), “The Moderating Effect of Generalized Anxiety and Financial Knowledge on Financial Management Behavior", Contemporary Family Therapy, Vol. 42 No. 1, pp. 15-24.

Grable, J.E., Park, J.-Y. and Joo, S.-H. (2009), "Explaining Financial Management Behavior for Koreans Living in the United States", Journal of Consumer Affairs, Vol. 43 No. 1, pp. 80107.

Grinstein-Weiss, M., Spader, J., Yeo, Y.H., Taylor, A. and Freeze, E.B. (2011), "Parental transfer of financial knowledge and later credit outcomes among low-and moderate-income homeowners", Children and Youth Services Review, Vol. 33 No. 1, pp. 78-85.

Grinstein-Weiss, M., Spader, J.S., Yeo, Y.H., Key, C.C. and Freeze, E.B. (2012), "Loan Performance among Low-Income Households: Does Prior Parental Teaching of Money Management Matter?", Social Work Research, Vol. 36 No. 4, pp. 257-270.

Gross, I. H., Crandall, E. W. and Knoll, M. M. (1980), Management for modern families, Englewood Cliffs, NJ: Prentice Hall, New York, the US.

Gudmunson, C.G. and Danes, S.M. (2011), "Family financial socialization: Theory and critical review", Journal of family and economic issues, Vol. 32 No. 4, pp. 644-667. 
Gunay, G., Boylu, A.A. and Oğuz, A. (2015), "Determinants of financial management behaviors of families", In Handbook of Research on Behavioral Finance and Investment Strategies: Decision Making in the Financial Industry, IGI Global, pp. 236-254.

Gunay, G., Savas, B., Gunes, H. and Bener, O. (2014), "Knowledge and Reported Behavior towards Banking Home Loans in a Sample of Turkish Consumers", The International Journal of Interdisciplinary Social and Community Studies, Vol. 8 No. 3, pp.25-37.

Guzman, F., Paswan, A. and Tripathy, N. (2019), "Consumer centric antecedents to personal financial planning", Journal of Consumer Marketing, Vol. 36 No. 6, p. 11.

Hanna, S.D., Lee, J. and Lindamood, S. (2015), "Financial Behavior and Attitudes of Asians Compared to Other Racial/Ethnic Groups in the United States", Journal of Family and Economic Issues, Vol. 36 No. 3, pp. 309-318.

Harari, M.B., Parola, H.R., Hartwell, C.J. and Riegelman, A. (2020), "Literature searches in systematic reviews and meta-analyses: A review, evaluation, and recommendations", Journal of Vocational Behavior, Vol. 118 No. 2020, p.103377.

Harrison, N. and Chudry, F. (2011), "Overactive, overwrought or overdrawn? The role of personality in undergraduate financial knowledge, decision-making and debt", Journal of Further and Higher Education, Vol. 35 No. 2, pp.149-182.

Hastings, J.S., Madrian, B.C. and Skimmyhorn, W.L. (2013), "Financial Literacy, Financial Education, and Economic Outcomes", Annual Review of Economics, Vol. 5 No. 1, pp. 347373.

Hastings, J. and Mitchell, O.S. (2020), "How financial literacy and impatience shape retirement wealth and investment behaviors", Journal of Pension Economics \& Finance, Vol. 19 No. 1, pp. 1-20.

Hayhoe, C.R., Cho, S.H., DeVaney, S.A., Worthy, S.L., Kim, J. and Gorham, E. (2012), "How Do Distrust and Anxiety Affect Saving Behavior?", Family and Consumer Sciences Research Journal, Vol. 41 No. 1, pp. 69-85.

Henchoz, C., Coste, T. and Wernli, B. (2019), "Culture, money attitudes and economic outcomes", Swiss Journal of Economics and Statistics, Vol. 155 No. 1, pp.1-13.

Hilgert, M.A., Hogarth, J.M. and Beverly, S.G. (2003), "Household financial management: The connection between knowledge and behavior", Fed. Res. Bull., Vol. 89, p.309.

Hira, T.K. and Mugenda, O.M. (1999), "The relationships between self-worth and financial beliefs, behavior, and satisfaction", Journal of family and consumer sciences, Vol. 91 No. 4, p.76.

Ho, C.S.M. and Lee, H.L.D. (2020), "Integrating positive financial attitudes to nurture students' identity as informed financial decision-makers in high power distance Chinese contexts", Journal of Educational Change, pp. 1-24.

Hofstede, G. (2001), Culture's consequences: Comparing values, behaviors, institutions and organizations across nations, Thousand Oaks: Sage publications, California, the US.

Hoffmann, A.O.I. and McNair, S.J. (2019), "How Does Consumers' Financial Vulnerability Relate to Positive and Negative Financial Outcomes? The Mediating Role of Individual Psychological Characteristics", Journal of Consumer Affairs, Vol. 53 No. 4, pp. 1630-1673.

Howlett, E., Kees, J. and Kemp, E. (2008), "The Role of Self-Regulation, Future Orientation, and Financial Knowledge in Long-Term Financial Decisions", Journal of Consumer Affairs, Vol. 42 No. 2, pp. 223-242.

Huston, S.J. (2010), “Measuring Financial Literacy”, Journal of Consumer Affairs, Vol. 44 No. 2 , pp. 296-316.

Joo S. (2008), "Personal Financial Wellness", Xiao J.J. (Ed.) Handbook of Consumer Finance Research, Springer, New York, NY.

Joo, S. and Grable, J.E. (2004), "An Exploratory Framework of the Determinants of Financial Satisfaction”, Journal of Family and Economic Issues, Vol. 25 No. 1, pp. 25-50. 
Jorgensen, B. L. (2007), "Financial literacy of college students: Parental and peer influences", Unpublished Masters Thesis, The Virginia Polytechnic Institute and State University.

Kahneman, D. and Tversky, A. (1979), "Prospect theory: An analysis of decision under risk", Econometrica, Vol. 47, pp. 263-292.

Kaiser, T. and Menkhoff, L. (2017), "Does Financial Education Impact Financial Behavior, and if So, When?", The World Bank Economic Review, Vol. 31. No. 3, pp. 611-630.

Kebede, M. and Kuar, J. (2015), "Financial Literacy and Management of Personal Finance: A Review of Recent Literatures", Research Journal of Finance and Accounting, Vol. 6 No. 13, pp. 92-106.

Kempson, E., Collard, S. and Moore, N. (2006), "Measuring financial capability: An exploratory study for the Financial Services Authority", Consumer financial capability: Empowering European consumers, p. 39.

Kerkmann, B.C., Lee, T.R., Lown, J.M. and Allgood, S.M. (2000), "Financial management, financial problems and marital satisfaction among recently married university students", Journal of Financial Counseling and Planning, Vol. 11 No. 2, p.55.

Keynes, John M. (1936), The General Theory of Employment, Interest and Money, Palgrave Macmillan, Harcourt, Brace, New York, NY.

Kidwell, B., Brinberg, D. and Turrisi, R. (2003), "Determinants of money management behavior", Journal of Applied Social Psychology, Vol. 33 No. 6, pp.1244-1260.

Kidwell, B. and Turrisi, R. (2004), "An examination of college student money management tendencies", Journal of Economic Psychology, Vol. 25 No. 5, pp. 601-616.

Kim, J., Garman, E. T., and Sorhaindo, B. (2003), "Relationship among credit counseling clients' financial wellbeing, financial behaviors, financial stressor events, and health", Financial Counseling and Planning, Vol. 14, pp. 75-87.

Kłopocka, A.M. (2017), "Does Consumer Confidence Forecast Household Saving and Borrowing Behavior? Evidence for Poland", Social Indicators Research, Vol. 133 No. 2, pp. 693-717.

Kulic, N., Minello, A. and Zella, S. (2020), "Manage Your Money, Be Satisfied? Money Management Practices and Financial Satisfaction of Couples Through the Lens of Gender", Journal of Family Issues, Vol. 41 No. 9, pp. 1420-1446.

Kumar, S., Tomar, S. and Verma, D. (2019), "Women's financial planning for retirement: Systematic literature review and future research agenda", International Journal of Bank Marketing, Vol. 37 No. 1, pp. 120-141.

Kusairi, S., Sanusi, N.A., Muhamad, S., Shukri, M. and Zamri, N. (2019), "Financial households' efficacy, risk preference and saving behaviour: Lessons from lower-income households in Malaysia", Economics \& Sociology, Vol. 12 No. 2, pp. 301-318.

Lai, M.M. and Tan, W.K. (2009), "An empirical analysis of personal financial planning in an emerging economy", European Journal of Economics, Finance and Administrative Sciences, Vol. 16 No. 1, pp. 99-111.

Lea, S.E.G., Webley, P. and Walker, C.M. (1995), "Psychological factors in consumer debt: Money management, economic socialization, and credit use", Journal of Economic Psychology, Vol. 16 No. 4, pp. 681-701.

LeBaron, A.B., Holmes, E.K., Jorgensen, B.L. and Bean, R.A. (2020), "Parental Financial Education During Childhood and Financial Behaviors of Emerging Adults", Journal of Financial Counseling and Planning. 10.1891/JFCP-18-00021

Lee, E. and Hanna, S.D. (2014), “Gender Differences of Asian College Students' Financial Knowledge Pathways", Asian Women, Vol. 30 No. 2, pp. 27-55.

Loke, Y.J. (2015), “Living beyond one's means: evidence from Malaysia", International Journal of Social Economics, Vol. 43 No. 1, pp. 2-18.

Lott, Y. (2017), "When My Money Becomes Our Money: Changes in Couples' Money Management”, Social Policy and Society, Vol. 16 No. 2, pp. 199-218. 
Loke, Y.-J. (2017a), “The Influence Of Socio-Demographic And Financial Knowledge Factors On Financial Management Practices Of Malaysians", International Journal of Business and Society, Vol. 18 No. 1, p.18.

Lusardi, A. (2008), "Household saving behavior: The role of financial literacy, information, and financial education programs (No. w13824)", National Bureau of Economic Research.

Lusardi, A. and Mitchell, O.S. (2007), "Financial literacy and retirement preparedness: Evidence and implications for financial education", Business economics, Vol. 42 No. 1, pp. 35-44.

Lusardi, A. and Mitchell, O.S. (2008), "Planning and financial literacy: How do women fare?", American Economic Review, Vol. 98 No. 2, pp. 413-17.

Lusardi, A. and Mitchell, O.S. (2011a), "Financial literacy around the world: an overview", Journal of Pension Economics and Finance, Vol. 10 No. 4, pp. 497-508.

Lusardi, A. and Mitchell, O.S. (2011), "Financial literacy and planning: Implications for retirement wellbeing (No. w17078)", National Bureau of Economic Research.

Lusardi, A. and Mitchell, O.S. (2014), "The economic importance of financial literacy: Theory and evidence", Journal of economic literature, Vol. 52 No. 1, pp. 5-44.

Lusardi, A., Michaud, P.C. and Mitchell, O.S. (2017), "Optimal financial knowledge and wealth inequality”, Journal of Political Economy, Vol. 125 No. 2, pp. 431-477.

Lusardi, A., Hasler, A. and Yakoboski, P.J. (2020), "Building up financial literacy and financial resilience", Mind \& Society, pp. 1-7. https://doi.org/10.1007/s11299-020-00246-0.

Lyssens-Danneboom, V. and Mortelmans, D. (2014), "Living Apart Together and Money: New Partnerships, Traditional Gender Roles", Journal of Marriage and Family, Vol. 76 No. 5, pp. 949-966.

Mandell, L. (2008), "Financial Literacy of High School Students", Xiao, J.J. (Ed.), Handbook of Consumer Finance Research, Springer, New York, NY, pp. 163-183.

Mandell, L. and Klein, L.S. (2009), "The impact of financial literacy education on subsequent financial behavior", Journal of Financial Counseling and Planning, Vol. 20 No. 1, p. 10.

Markowitz, H. (1952), "Portfolio selection”, Journal of Finance, Vol. 7 No. 1, pp. 77-91.

Maslow, A. H. (1943), “A theory of human motivation”, Psychological Review, Vol. 50, pp. 370396.

McHugh, S. and Ranyard, R. (2012), "Credit repayment decisions: The role of long-term consequence information, economic and psychological factors", Review of Behavioural Finance, Vol. 4 No. 2, pp. 98-112.

McKenna, J., Hyllegard, K. and Linder, R. (2003), "Linking psychological type to financial decision-making”, Journal of Financial Counseling and Planning, Vol. 14 No. 1, p. 11.

McNair, S., Summers, B., de Bruin, W.B. and Ranyard, R. (2016), "Individual-level factors predicting consumer financial behavior at a time of high pressure", Personality and Individual Differences, Vol. 99, pp. 211-216.

Miotto, A.P.S.C. and Parente, J. (2015), “Antecedents And Consequences Of Household Financial Management In Brazilian Lower-Middle-Class”, Revista de Administração de Empresas, Vol. 55 No. 1, pp. 50-64.

Moreland, K.A. (2018), "Seeking Financial Advice and Other Desirable Financial Behaviors", Journal of Financial Counseling and Planning, Vol. 29 No. 2, pp. 198-207.

Morgan, P.J. and Trinh, L.Q. (2019), "Fintech and Financial Literacy in the Lao PDR", SSRN Electronic Journal. https://doi.org/10.2139/ssrn.3398235.

Moschis, G.P. (1987), Consumer socialization: A life-cycle perspective, Free Press, New York, NY.

Mugenda, O.M., Hira, T.K. and Fanslow, A.M. (1990), "Assessing the causal relationship among communication, money management practices, satisfaction with financial status, and satisfaction with quality of life", Lifestyles Family and Economic Issues, Vol. 11 No. 4, pp. 343-360. 
Mullis, R.J. and Schnittgrund, K.P. (1982), "Budget Behaviour: Variance Over The Life Cycle Of Low Income Families", Journal of Consumer Studies and Home Economics, Vol. 6 No. 2, pp. $113-119$.

Navickas, M., Gudaitis, T. and Krajnakova, E. (2014), "Influence of financial literacy on management of personal finances in a young household", Business: theory and practice, Vol. 15 No. 1, pp. 32-40.

Nejad, M.G. and Javid, K. (2018), "Subjective and objective financial literacy, opinion leadership, and the use of retail banking services", International Journal of Bank Marketing, Vol. 36 No. 4, pp. 784-804.

Netemeyer, R.G., Warmath, D., Fernandes, D. and Lynch Jr, J.G. (2018), "How am I doing? Perceived financial well-being, its potential antecedents, and its relation to overall well-being", Journal of Consumer Research, Vol. 45 No. 1, pp. 68-89.

NFCC. (2020), "Consumer Financial Literacy Survey. The Harris Poll”, Harris Insights and Analytics LLC, A Stagwell Company, available at: https://www.nfcc.org/wpcontent/themes/foundation/assets/files/NFCC Discover_2020 FLS_Datasheet $\% 20 \mathrm{With} \% 20$ Key\%20Findings Clean.pdf (accessed on 20 November 2020).

Norvilitis, J.M., Merwin, M.M., Osberg, T.M., Roehling, P.V., Young, P. and Kamas, M.M. (2006), "Personality Factors, Money Attitudes, Financial Knowledge, and Credit-Card Debt in College Students", Journal of Applied Social Psychology, Vol. 36 No. 6, pp. 1395-1413.

Nuspl, L.M. (1972), "Personal financial management. I. Paving your own road to success", Canadian Medical Association Journal, Vol. 107 No. 1, p.75.

OECD. (2009), Financial Literacy and Consumer Protection: Overlooked Aspects of the Crisis, OECD.

OECD. (2014), "PISA 2012 technical background", in OECD (Ed.), PISA 2012 Results: Students and Money: Financial Literacy Skills for the 21st Century, Vol. VI, OECD Publishing, Paris, pp. 123-145.

Pahl, J. (1989), Money and marriage. Macmillan, New York, NY.

Pak, T.Y. and Chatterjee, S. (2016), "Savings decisions of American households: The roles of financial literacy and financial practice" Economics Bulletin, Vol. 36 No. 3, pp. 1486-1496.

Panos, G.A. and Wilson, J.O.S. (2020), "Financial literacy and responsible finance in the FinTech era: capabilities and challenges", The European Journal of Finance, Vol. 26 No. 4-5, pp. $297-$ 301.

Pepin, J.R. (2019), "Beliefs about money in families: Balancing unity, autonomy, and gender equality", Journal of Marriage and Family, Vol. 81 No. 2, pp. 361-379.

Perry, V.G. and Morris, M.D. (2005), "Who Is in Control? The Role of Self-Perception, Knowledge, and Income in Explaining Consumer Financial Behavior", Journal of Consumer Affairs, Vol. 39 No. 2, pp. 299-313.

Pirouz, D. (2009), "Culture, Self-Control, and Consumer Financial Behavior", McGill, A. L. and Shavitt, S. (Ed.s), Advances in Consumer Research, Duluth, MN : Association for Consumer Research, NA, pp. 908-909.

Ponchio, M.C., Cordeiro, R.A. and Gonçalves, V.N. (2019), "Personal factors as antecedents of perceived financial well-being: evidence from Brazil”, International Journal of Bank Marketing, Vol. 37 No. 4, pp. 1004-1024.

Porter, N. M., and Garman, E. T. (1993), "Testing a conceptual model of financial well-being”, Financial Counselling and Planning, Vol. 4, pp. 135-164.

Prochaska, J.O. and DiClemente, C.C. (1982), "Transtheoretical therapy: toward a more integrative model of change", Psychotherapy: theory, research \& practice, Vol. 19 No. 3, p. 276.

Prochaska-Cue, K. (1993), "An exploratory study for a model of personal financial management style”, Journal of Financial Counseling and Planning, Vol. 4, pp. 111-134. 
Rashman, L., Withers, E. and Hartley, J. (2009), "Organizational learning and knowledge in public service organizations: A systematic review of the literature", International Journal of Management Reviews, Vol. 11 No. 4, pp. 463-494.

Rebouças, R. and Soares, A.M. (2020), "Voluntary simplicity: A literature review and research agenda.", International Journal of Consumer Studies. https://doi.org/10.1111/ijcs.12621

Reynolds, L. M. and Abdel-Ghany, M. (2001), "Consumer sciences research: A two-decade comparison, 1980s and 1990s", Family and Consumer Sciences Research Journal, Vol. 29, pp. 382-440.

Richins, M.L. (2004), “The Material Values Scale: Measurement Properties and Development of a Short Form”, Journal of Consumer Research, Vol. 31 No. 1, pp. 209-219.

Riitsalu, L. and Murakas, R. (2019), "Subjective financial knowledge, prudent behaviour and income: The predictors of financial well-being in Estonia", International Journal of Bank Marketing, Vol. 37 No. 4, pp. 934-950.

Rodrigues, S.P., Sousa, L. and Alarcão, M.M. (2016), "Financial management in long-term lowincome households: comparing perspectives of professionals and families in Portugal", European Journal of Social Work, Vol. 19 No. 6, pp. 977-991.

Sachitra, V., Wijesinghe, D. and Gunasena, W. (2019), "Exploring undergraduates' moneymanagement life: insight from an emerging economy", Young Consumers, Vol. 20 No. 3, pp. $167-189$.

Salignac, F., Marjolin, A., Reeve, R. and Muir, K. (2019), "Conceptualizing and Measuring Financial Resilience: A Multidimensional Framework", Social Indicators Research, Vol. 145 No. 1, pp. 17-38.

Sargent, T.J. (1987), "Rational expectations", Newman, P., Eatwell, J. and Milgate, M. (Ed.s), The New Palgrave: A Dictionary of Economics, Palgrave Macmillan, New York, NY, pp. 76-79.

Scannell, E. (1990), “Dairy Farm Families’ Financial Management”, Financial Management, Vol. 1, p. 14.

Schuchardt, J., Bagwell, D.C., Bailey, W.C., DeVaney, S.A., Grable, J.E., Leech, I.E., Lown, J.M., et al. (2007), "Personal Finance: An Interdisciplinary Profession", Journal of Financial Counseling and Planning, Vol. 18 No. 1, p. 9.

Schuchardt, J., Hanna, S.D., Hira, T.K., Lyons, A.C., Palmer, L. and Xiao, J.J. (2009), "Financial literacy and education research priorities", Journal of Financial Counseling and Planning, Vol. 20 No. 1.

Sharpe, W.F. (1964), "Capital asset prices: a theory of market equilibrium under conditions of risk", Journal of Finance, Vol. 19 No. 3, pp. 425-442.

Shim, S., Barber, B.L., Card, N.A., Xiao, J.J. and Serido, J. (2010), "Financial Socialization of Firstyear College Students: The Roles of Parents, Work, and Education", Journal of Youth and Adolescence, Vol. 39 No. 12, pp.1457-1470.

Shim, S., Xiao, J.J., Barber, B.L. and Lyons, A.C. (2009), "Pathways to life success: A conceptual model of financial well-being for young adults", Journal of Applied Developmental Psychology, Vol. 30 No. 6, pp. 708-723.

Singh, S. and Bhandari, M. (2012), "Money Management and Control in the Indian Joint Family across Generations", The Sociological Review, Vol. 60 No. 1, pp. 46-67.

Skimmyhorn, W. (2016), "Assessing Financial Education: Evidence from Boot Camp", American Economic Journal: Economic Policy, Vol. 8 No. 2, pp. 322-343.

Spinella, M., Yang, B. and Lester, D. (2007), "Development of the executive personal finance scale", International Journal of Neuroscience, Vol. 117 No. 3, pp. 301-313.

Spuhlera, B.K. and Dew, J. (2019), "Sound Financial Management and Happiness: Economic Pressure and Relationship Satisfaction as Mediators", Journal of Financial Counseling and Planning, Vol. 30 No. 2, pp. 157-174. 
Stendardi, E.J., Graham, J.F. and O'Reilly, M. (2006), “The impact of gender on the personal financial planning process", Humanomics, Vol. 22 No. 4, pp. 223-238.

Stevenson, B. and Wolfers, J. (2013), "Subjective well-being and income: Is there any evidence of satiation?", American Economic Review, Vol. 103 No. 3, pp. 598-604.

Sundarasen, S.D.D. and Rahman, M.S. (2017), "Attitude towards money: Mediation to money management", Academy of Accounting and Financial Studies Journal, Vol. 21 No. 1, pp. 8096.

Sonnenberg, S.J. (2018), "22 The Economic Psychology of Financial Decision-Making and Money Management in the Household", Centre For Decision Research, University Of Leeds, Uk, p.354.

Sonnenberg, S.J., Burgoyne, C.B. and Routh, D.A. (2011), "Income disparity and norms relating to intra-household financial organisation in the UK: A dimensional analysis", The Journal of Socio-Economics, Vol. 40 No. 5, pp. 573-582.

Tang, N. and Baker, A. (2016), "Self-esteem, financial knowledge and financial behavior", Journal of Economic Psychology, Vol. 54, pp. 164-176.

Taylor, M. (2011), "Measuring financial capability and its determinants using survey data", Social Indicators Research, Vol. 102 No. 2, pp. 297-314.

Thaler, R. (1985), "Mental accounting and consumer choice”, Marketing Science, Vol. 4 No. 3, pp. 199-214.

Thaler, R. H. and Shefrin, H. M. (1981), “An economic theory of self- control”, Journal of Political Economy, Vol. 89 No. 2, pp. 392-406.

Thibault, J. W. and Kelley, H. H. (1959), The social psychology of groups, Wiley, New York, NY.

Titus, P.M., Fanslow, A.M. and Hira, T.K. (1989), "Net Worth and Financial Satisfaction as a Function of Household Money Managers' Competencies", Home Economics Research Journal, Vol. 17 No. 4, pp. 309-318.

Topa, G., Hernández-Solís, M. and Zappalà, S. (2018), "Financial Management Behavior Among Young Adults: The Role of Need for Cognitive Closure in a Three-Wave Moderated Mediation Model", Frontiers in Psychology, 9, p. 2419.

Tranfield, D., Denyer, D. and Smart, P. (2003), "Towards a Methodology for Developing EvidenceInformed Management Knowledge by Means of Systematic Review", British Journal of Management, Vol. 14 No. 3, pp. 207-222.

Triandis, H.C. (1994), “Culture And Social Behavior”, p. 1.

Tufano, P. (2009), "Consumer finance”, Annual Review Financial Economics, Vol. 1 No. 1, pp. 227-247.

van Deventer, M. (2019), 'Differences in black Generation Y students' attitudes towards personal financial planning and perceived financial-management skills based on selected demographic factors", Polish Journal of Management Studies, Vol. 19 No. 2, p. 13.

van Deventer, M., de Klerk, N. and Bevan-Dye, A.L. (2014), "African Generation Y students' attitudes towards personal financial planning”, Mediterranean Journal of Social Sciences, Vol. 5 No. 21, pp. 111-111.

Van Raaij, W.F. (2016), Understanding consumer financial behavior: Money management in an age of financial illiteracy, Springer, Germany.

Van Rooij, M.C.J., Lusardi, A. and Alessie, R.J.M. (2011), "Financial literacy and retirement planning in the Netherlands", Journal of Economic Psychology, Vol. 32 No. 4, pp. 593-608.

Vogler, C., Brockmann, M. and Wiggins, R.D. (2006), "Intimate relationships and changing patterns of money management at the beginning of the twenty-first century", The British Journal of Sociology, Vol. 57 No. 3, pp. 455-482.

Vogler, C., Lyonette, C. and Wiggins, R.D. (2008), "Money, Power and Spending Decisions in Intimate Relationships”, The Sociological Review, Vol. 56 No. 1, pp. 117-143. 
Vosylis, R. and Erentaite, R. (2019), "Linking Family Financial Socialization With Its Proximal and Distal Outcomes: Which Socialization Dimensions Matter Most for Emerging Adults' Financial Identity, Financial Behaviors, and Financial Anxiety?", Emerging Adulthood, Vol. 8 No. 6, pp. 464-475.

Waller, W. and Hill, R. (1951), The family: A dynamic interpretation, Dryden Press, New York, NY.

Webster, D.M. and Kruglanski, A.W. (1994), "Individual differences in need for cognitive closure", Journal of personality and social psychology, Vol. 67 No. 6, p.1049.

West, T. and Worthington, A. (2019), "The impact of major life events on household asset portfolio rebalancing", Studies in Economics and Finance, Vol. 36 No. 3, pp. 334-347.

Wiepking, P. and Bekkers, R. (2010), "Does who decides really matter? Causes and consequences of personal financial management in the case of larger and structural charitable donations", Voluntas: International Journal of Voluntary and Nonprofit Organizations, Vol. 21 No. 2, pp. 240-263.

Xiao, J.J. (2008), “Applying Behavior Theories to Financial Behavior”, Xiao, J.J. (Ed.), Handbook of Consumer Finance Research, Springer New York, New York, NY, pp. 69-81.

Xiao, J.J. (2015), "Consumer economic wellbeing", In Xiao, J.J. (Ed.), Consumer economic wellbeing, Springer, New York, NY, pp. 3-21.

Xiao, J.J., Chen, C. and Chen, F. (2014), "Consumer Financial Capability and Financial Satisfaction”, Social Indicators Research, Vol. 118 No. 1, pp. 415-432.

Xiao, J. J., Chen, C., and Sun, L. (2015), "Age differences in consumer financial capability", International Journal of Consumer Studies, Vol. 39 No. 4, pp. 387-395.

Xiao, J.J., Collins, M., Ford, M., Keller, P., Kim, J. and Robles, B. (2010), “A review of financial behavior research: Implications for financial education.", Commissioned report submitted to National Endowment on Financial Education.

Xiao, J.J., Ford, M.W. and Kim, J. (2011), "Consumer Financial Behavior: An Interdisciplinary Review of Selected Theories and Research: Consumer Financial Behavior", Family and Consumer Sciences Research Journal, Vol. 39 No. 4, pp. 399-414.

Xiao, J. J., Newman, B. M., Prochaska, J. M., Leon, B., Bassett, R., and Johnson, J. L. (2004a), "Applying the transtheoretical model of change to debt reducing behavior", Financial Counseling and Planning, Vol. 15 No. 2, pp. 89-100.

Xiao, J.J., O'Neill, B., Prochaska, J.M., Kerbel, C.M., Brennan, P. and Bristow, B.J. (2004b). “A consumer education programme based on the transtheoretical model of change", International Journal of Consumer Studies, Vol. 28 No. 1, pp.55-65.

Xiao, J. J., and O’Neill, B. (2016), "Consumer financial education and financial capability", International Journal of Consumer Studies, Vol. 40 No. 6, pp. 712-721.

Xiao, J.J. and O'Neill, B. (2018a), "Mental accounting and behavioural hierarchy: Understanding consumer budgeting behaviour", International Journal of Consumer Studies, Vol. 42 No. 4, pp. 448-459.

Xiao, J.J. and O'Neill, B. (2018b), "Propensity to plan, financial capability, and financial satisfaction", International Journal of Consumer Studies, Vol. 42 No. 5, pp. 501-512.

Xiao, J. J. and Porto, N. (2017), "Financial education and financial satisfaction: Financial literacy, behavior, and capability as mediators", International Journal of Bank Marketing, Vol. 35 No. 5, pp. 805-817.

Xiao, J.J. and Porto, N. (2019), "Present bias and financial behavior", Financial Planning Review, Vol. 2 No. 2, p. e1084.

Xiao, J.J. and Tao, C. (2020), "Consumer finance/household finance: the definition and scope", China Finance Review International, ahead-of-print (ahead-of-print), https://doi.org/10.1108/CFRI-04-2020-0032 
Xiao, J. J., Tang, C., and Shim, S. (2009), "Acting for happiness: Financial behavior and life satisfaction of college students", Social Indicators Research, Vol. 92, pp. 53-68.

$\mathrm{Xu}, \mathrm{L}$. and Zia, B. (2012), Financial literacy around the world: an overview of the evidence with practical suggestions for the way forward, The World Bank, p. 58.

Xu, Y., Briley, D.A., Brown, J.R. and Roberts, B.W. (2017), "Genetic and environmental influences on household financial distress", Journal of Economic Behavior \& Organization, Vol. 142, pp. 404-424.

Xu, Y., Beller, A.H., Roberts, B.W. and Brown, J.R. (2015), "Personality and young adult financial distress.", Journal of Economic Psychology, Vol. 51, pp. 90-100.

Yakoboski, P.J., Lusardi, A. and Hasler, A. (2020), "The 2020 TIAA Institute-GFLEC Personal Finance Index", p. 29, available at: https:/www.tiaainstitute.org/publication/2020-tiaainstitute-gflec-personal-finance-index (accessed on 10 November 2020).

Zulfaris, M.D., Mustafa, H., Mahussin, N., Alam, M.K. And Daud, Z.M. (2020), "Students and Money Management Behavior of a Malaysian Public University", The Journal of Asian Finance, Economics and Business, Vol. 7 No. 3, pp. 245-251. 
Table I. A summary of extant reviews on PFMB

\begin{tabular}{lll}
\hline Author(s) & Focus of the Review & $\begin{array}{l}\text { Article } \\
\text { Type }\end{array}$ \\
\hline Lusardi and Mitchell (2007) & $\begin{array}{l}\text { Levels of FL and the linkage of FL with } \\
\text { retirement preparedness }\end{array}$ & $\begin{array}{l}\text { Review }+ \\
\text { Conceptual }\end{array}$ \\
\hline Schuchardt (2007) & $\begin{array}{l}\text { History of personal finance and summary of } \\
\text { conceptual foundation }\end{array}$ & Review \\
\hline Xiao et al. (2011) & Review of few theories on PFMB & Review \\
\hline Hastings et al. (2013) & $\begin{array}{l}\text { Impact of financial education on FL and } \\
\text { financial outcomes }\end{array}$ & Review \\
\hline Fernandes et al. (2014) & $\begin{array}{l}\text { Impact of FL and financial education on } \\
\text { financial behaviour }\end{array}$ & $\begin{array}{l}\text { Meta- } \\
\text { analysis }\end{array}$ \\
\hline Kebede et al. (2015) & FL and personal financial management & Review \\
\hline Kumar et al. (2018) & Women's retirement financial planning & $\begin{array}{l}\text { Systematic } \\
\text { literature } \\
\text { review }\end{array}$ \\
\hline Sonnenberg (2018) & Psychology of household money management & Review \\
\hline Xiao and Tao (2020) & $\begin{array}{l}\text { Definition and the scope of consumer } \\
\text { finance/Household finance/Personal finance }\end{array}$ & $\begin{array}{l}\text { Review }+ \\
\text { Conceptual }\end{array}$ \\
\hline
\end{tabular}


Table II. Database and search string used for data retrieval

\begin{tabular}{|l|l|}
\hline Database & Search String \\
\hline Scopus and Web of Science & "personal financ* management" OR "personal financ* \\
behavi?r*" OR "personal financ* planning" OR "personal \\
financ* management behavi?r* OR "financ* \\
management behavi?r" OR "manag* personal financ*" \\
OR "personal financ* decision*" OR "personal financ* \\
outcome*" OR "household financ* management" OR \\
"household financ* behavi?r" OR "household financ* \\
planning" OR "famil* financ* management" OR "famil* \\
financ* planning" OR "famil* financ* behavi?r" OR \\
"individual financ* management" OR "individual financ* \\
planning" OR "individual financ* behavi?r" OR \\
"consumer financ* behavi?r" OR "consumer financ* \\
planning" OR "consumer financ* management" OR \\
"money management"
\end{tabular}


Table III. Definitions of PFMB

\begin{tabular}{ll}
\hline Author(s) & Definitions \\
\hline Deacon and Firebaugh & $\begin{array}{l}\text { Performance of behaviours regarding planning, implementing, and } \\
\text { evaluating decisions associated with cash, credit management, } \\
\text { investments, insurance, and retirement and estate planning. }\end{array}$ \\
\hline Pahl (1989) & $\begin{array}{l}\text { It is defined as the income allocation within the household: female } \\
\text { whole wage system, male whole wage system, joint pooling, } \\
\text { household allowance or independent money management. }\end{array}$ \\
\hline Altfest (2004) & $\begin{array}{l}\text { It is a process which incorporates all components which are of } \\
\text { financial interest to the individuals. These comprise of cash flow } \\
\text { management, investments, risk management, retirement planning, } \\
\text { tax planning and estate planning. }\end{array}$ \\
\hline Schuchardt et al. (2007) & $\begin{array}{l}\text { It consists of tools like financial statements, checking and savings } \\
\text { accounts, debt instruments, mortgages and investment vehicles. }\end{array}$ \\
\hline Joo (2008) & $\begin{array}{l}\text { Efficient personal financial behavior is corollary to positive } \\
\text { financial well-being and failing in managing personal finances can } \\
\text { lead to severe long term consequences. }\end{array}$ \\
\hline Dew and Xiao (2011) & $\begin{array}{l}\text { The financial behaviors include consumption, cash flow } \\
\text { management, savings and investment, credit and insurance. }\end{array}$ \\
\hline
\end{tabular}


Table IV. A Summary of Theories Used

\begin{tabular}{|c|c|c|c|}
\hline S. No. & Theory & Origin & Example Citations \\
\hline 1 & Motives Theory & Keynes (1936) & Copur and Gutter (2019) \\
\hline 2 & $\begin{array}{l}\text { Maslow's Need Hierarchy } \\
\text { Theory }\end{array}$ & Maslow (1943) & Spuhlera and Dew (2019) \\
\hline 3 & Role Theory & $\begin{array}{l}\text { Waller and Hill } \\
\text { (1951) }\end{array}$ & Kerkmann et al. (2000) \\
\hline 4 & Modern Portfolio Theory & Markowitz (1952) & Guzman and Paswan (2019) \\
\hline 5 & Social Exchange Theory & $\begin{array}{l}\text { Thibault and } \\
\text { Kelley (1959) }\end{array}$ & Kerkmann et al. (2000) \\
\hline 6 & Life Cycle Hypothesis & $\begin{array}{l}\text { Ando and } \\
\text { Modigliani (1963) }\end{array}$ & $\begin{array}{l}\text { Copur and Gutter (2019); } \\
\text { Bialowolski (2019); Panos and } \\
\text { Wilson (2020) }\end{array}$ \\
\hline 7 & Asset Pricing Models & Sharpe (1964) & Guzman and Paswan (2019) \\
\hline 8 & Efficient Market Hypothesis & Fama (1970) & $\begin{array}{l}\text { Guzman and Paswan (2019); } \\
\text { Kusairi et al. (2019) }\end{array}$ \\
\hline 9 & Rational Behavior Theory & $\begin{array}{l}\text { Ajzen and } \\
\text { Fishbein (1973) }\end{array}$ & Lee and Hanna (2014) \\
\hline 10 & Theory of Reasoned Action & $\begin{array}{l}\text { Fishbein and } \\
\text { Ajzen (1975) }\end{array}$ & Kidwell and Turrisi (2004) \\
\hline 11 & Self- Efficacy Concept & Bandura (1977) & $\begin{array}{l}\text { Xiao et al. (2014); Gamst- } \\
\text { Klaussen et al. (2019) }\end{array}$ \\
\hline 12 & Social Learning Theory & $\begin{array}{l}\text { Bandura and } \\
\text { Walters (1977) }\end{array}$ & Sachitra et al. (2018) \\
\hline 13 & Prospect Theory & $\begin{array}{l}\text { Kahneman and } \\
\text { Tversky (1979) }\end{array}$ & Cho et al. (2016) \\
\hline 14 & Theory of Self Control & $\begin{array}{l}\text { Thaler and Shefrin } \\
\text { (1981) }\end{array}$ & Xiao and Porto (2019) \\
\hline 15 & $\begin{array}{l}\text { Transtheoretical Model of } \\
\text { Change }\end{array}$ & $\begin{array}{l}\text { Prochaska } \\
\text { and DiClemente } \\
(1982)\end{array}$ & Bapat (2020) \\
\hline 16 & Theory of Mental Accounting & Thaler (1985) & $\begin{array}{l}\text { Antonides et al. (2011); Miotto } \\
\text { and Parente (2015) }\end{array}$ \\
\hline 17 & $\begin{array}{l}\text { Theory of consumer } \\
\text { Socialization }\end{array}$ & Moschis (1987) & $\begin{array}{l}\text { Fulk and White (2018); Antoni et } \\
\text { al. (2019) }\end{array}$ \\
\hline 18 & Rational Expectations Theory & Sargent (1987) & $\begin{array}{l}\text { Guzman and Paswan (2019); } \\
\text { Kusairi et al. (2019) }\end{array}$ \\
\hline 19 & $\begin{array}{l}\text { Family Resource } \\
\text { Management Model }\end{array}$ & $\begin{array}{l}\text { Deacon and } \\
\text { Firebaugh (1988) }\end{array}$ & Mugenda et al. (1990) \\
\hline 20 & Social Cognitive Theory & Bandura (1989) & $\begin{array}{l}\text { Copur and Gutter (2019); } \\
\text { Asandimitra and Kautsar (2019) }\end{array}$ \\
\hline 21 & Theory of Planned Behavior & Ajzen (1991) & $\begin{array}{l}\text { Kidwell and Turrisi (2004); } \\
\text { Copur and Gutter (2019); Barbic } \\
\text { et al. (2019); Bapat (2020) }\end{array}$ \\
\hline 22 & Theory of Social Behavior & Triandis (1994) & Kidwell and Turrisi (2004) \\
\hline 23 & $\begin{array}{l}\text { Hofstede's Cultural Value } \\
\text { Dimensions }\end{array}$ & Hofstede (2001) & Ho and Lee (2020) \\
\hline 24 & Couples and Finances Theory & Archuleta (2008) & Baryła-Matejczuk et al. (2020) \\
\hline
\end{tabular}


Table V. Top regions and top countries in PFMB research based on sample segregation

\begin{tabular}{cccc}
\hline & Single Country (n=144) & $\begin{array}{c}\text { Multi } \\
\text { Country } \\
(\mathbf{n = 5})\end{array}$ & $\begin{array}{c}\text { No } \\
\text { country } \\
\text { Specific } \\
(\mathbf{n}=\mathbf{1 1})\end{array}$ \\
\hline Region & Country & $\begin{array}{c}\text { Number of } \\
\text { Publications }\end{array}$ & \\
\hline America & US & 60 \\
\cline { 2 - 3 } & Brazil & 1 \\
\hline Europe & Canada & 1 \\
\cline { 2 - 3 } & UK & 17 \\
\cline { 2 - 3 } & Poland & 5 \\
\hline Asia & Turkey & 4 \\
\cline { 2 - 3 } & Malaysia & 10 \\
\hline Australia & India & 6 \\
\hline Africa & China & 3 \\
\hline & Indonesia & 3 \\
\hline
\end{tabular}


Table VI. Most prominent existing PFMB scales

\begin{tabular}{|c|c|c|}
\hline Existing Scales of PFMB & Variables & Reference \\
\hline $\begin{array}{l}\text { Frequency of Financial } \\
\text { Management Scale }\end{array}$ & $\begin{array}{l}\text { Planning regarding usage of money; } \\
\text { Tracking spending; Written budget }\end{array}$ & $\begin{array}{l}\text { Fitzsimmons et al. } \\
\text { (1993) }\end{array}$ \\
\hline $\begin{array}{l}\text { Financial Management } \\
\text { Behaviors Scale }\end{array}$ & $\begin{array}{l}\text { Consumption; Credit; Cash; Saving; } \\
\text { Investment; Risk; Capital; Retirement }\end{array}$ & $\begin{array}{l}\text { Porter \& Garman } \\
\text { (1993) }\end{array}$ \\
\hline $\begin{array}{l}\text { The Prochaska-Cue } \\
\text { Inventory of Financial } \\
\text { Management Style (PIFS) }\end{array}$ & $\begin{array}{l}\text { Estate planning; Insurance; Financial } \\
\text { record keeping; Budgeting; Saving; } \\
\text { Investing }\end{array}$ & $\begin{array}{l}\text { Prochaska-Cue } \\
\text { (1993) }\end{array}$ \\
\hline $\begin{array}{l}\text { Household Financial } \\
\text { Management Practices Index }\end{array}$ & $\begin{array}{l}\text { Cash flow management; Credit } \\
\text { management; Savings; Investment }\end{array}$ & Hilgert et al. (2003) \\
\hline Financial Behavior Scale & $\begin{array}{l}\text { Planning; Saving; Budgeting; Cutting } \\
\text { down spending; Credit management }\end{array}$ & Kim et al. (2003) \\
\hline Financial Behavior Scale & $\begin{array}{l}\text { Budgeting; Saving; Controlling } \\
\text { spending }\end{array}$ & $\begin{array}{l}\text { Perry and Morris } \\
(2005)\end{array}$ \\
\hline $\begin{array}{l}\text { College Student Financial } \\
\text { Literacy Survey (Financial } \\
\text { behavior) }\end{array}$ & $\begin{array}{l}\text { Budgeting; Tracking spending; } \\
\text { Savings; Borrowing; Insurance }\end{array}$ & Jorgensen (2007) \\
\hline $\begin{array}{l}\text { Executive Personal Finance } \\
\text { Scale }\end{array}$ & $\begin{array}{l}\text { Impulse control; Organization; } \\
\text { Planning; Motivational drive }\end{array}$ & Spinella et al. (2007) \\
\hline Financial Behavior Scale & $\begin{array}{l}\text { Cash management; Credit } \\
\text { Management; Saving }\end{array}$ & Xiao et al. (2008) \\
\hline $\begin{array}{l}\text { The Financial Management } \\
\text { Behavior Scale }\end{array}$ & $\begin{array}{l}\text { Consumption; Credit; Cash; Saving; } \\
\text { Investment }\end{array}$ & $\begin{array}{l}\text { Dew and Xiao } \\
\text { (2011) }\end{array}$ \\
\hline Money Management Scale & $\begin{array}{l}\text { Basic financial management } \\
\text { tendencies }\end{array}$ & $\begin{array}{l}\text { Garðarsdóttir and } \\
\text { Dittmar (2012) }\end{array}$ \\
\hline $\begin{array}{l}\text { OECD/INFE Financial } \\
\text { Behavior Scale }\end{array}$ & $\begin{array}{l}\text { Consumption; Cash flow } \\
\text { management; Long term financial } \\
\text { goal setting; Responsible budgeting; } \\
\text { Active saving; Borrowing }\end{array}$ & $\begin{array}{l}\text { Atkinson and Messy } \\
(2012)\end{array}$ \\
\hline
\end{tabular}


Table VII. Classification of 160 studies based on research methods, research designs, data collection approach and data analysis tools

\begin{tabular}{|c|c|c|c|c|c|}
\hline Research Method & Research Design & $\begin{array}{l}\text { Data Collection } \\
\text { Technique }\end{array}$ & $\begin{array}{l}\text { Data Analysis } \\
\text { Approach }\end{array}$ & $\begin{array}{l}\text { Sub Classification in } \\
\text { Analysis tool }\end{array}$ & Example Citations \\
\hline \multirow[t]{12}{*}{ Empirical $(n=145)$} & Quantitative $(\mathrm{n}=121)$ & Survey $(n=113)$ & Descriptive & & $\begin{array}{l}\text { Hilgert et al. (2003); Mandell (2008); } \\
\text { Boon et al. (2011); Lusardi et al. } \\
(2020)\end{array}$ \\
\hline & & & Correlation & & $\begin{array}{l}\text { Scannell (1990); Grable et al. (2009); } \\
\text { McHugh and Ranyard (2012); } \\
\text { Eberhardt et al. (2019) }\end{array}$ \\
\hline & & & $\begin{array}{l}\text { ANOVA (Analysis of } \\
\text { Variance) }\end{array}$ & & $\begin{array}{l}\text { Lai and Tan (2009); Nejad and Javid } \\
\text { (2018); Xiao and O'Neill (2018b) }\end{array}$ \\
\hline & & & T-Test & & $\begin{array}{l}\text { Lai and Tan (2009); Grable et al. } \\
\text { (2009); Van Deventer et al. (2014) }\end{array}$ \\
\hline & & & Chi-Square Test & & $\begin{array}{l}\text { Mullis and Schnittgrund (1982); } \\
\text { Mandell and Klein (2009) }\end{array}$ \\
\hline & & & Regression & Multiple Regression & $\begin{array}{l}\text { Godwin and Carroll (1986); Perry and } \\
\text { Morris (2005); Harrison and Chudry } \\
\text { (2011); Guzman et al. (2019) }\end{array}$ \\
\hline & & & & Logistic Regression & $\begin{array}{l}\text { Gorniak (1999); Fulk and White } \\
\text { (2018); Pepin (2019) }\end{array}$ \\
\hline & & & & Linear Regression & $\begin{array}{l}\text { Kidwell and Turrisi (2004); Henchoz } \\
\text { et al. (2019); Birkenmaier and Fu } \\
\text { (2019) }\end{array}$ \\
\hline & & & & $\begin{array}{l}\text { OLS (Ordinary Least } \\
\text { Squares Regression) }\end{array}$ & $\begin{array}{l}\text { Kidwell et al. (2003); Wiepking and } \\
\text { Bekkers (2010); Xiao and Porto } \\
\text { (2019); Bapat (2020) }\end{array}$ \\
\hline & & & & $\begin{array}{l}\text { Hierarchical } \\
\text { Regression }\end{array}$ & $\begin{array}{l}\text { Hayhoe et al. (2012); Gunay et al. } \\
\text { (2014); Hoffman and McNair (2019) }\end{array}$ \\
\hline & & & & Sobel Regression & Grable et al. (2009) \\
\hline & & & & Probit Regression & $\begin{array}{l}\text { Allgood and Walstad (2013); Hanna et } \\
\text { al. (2015); Loke (2017a) }\end{array}$ \\
\hline
\end{tabular}




\begin{tabular}{|c|c|c|c|c|c|}
\hline & & & & Logit Regression & $\begin{array}{l}\text { Lea et al. (1995); Pak and Chatterjee } \\
\text { (2016); Hastings and Mitchell (2020) }\end{array}$ \\
\hline & & & & Cox Regression & Grinstein et al. (2012) \\
\hline & & & & Tobit Regression & $\begin{array}{l}\text { Grinstein et al. (2011); West and } \\
\text { Worthington (2019) }\end{array}$ \\
\hline & & & & $\begin{array}{l}\text { SUR(Seemingly } \\
\text { Unrelated )Regression }\end{array}$ & Farrell et al. (2016) \\
\hline & & & & $\begin{array}{l}\text { Hybrid Panel } \\
\text { Regression }\end{array}$ & Lott (2017) \\
\hline & & & $\begin{array}{l}\text { SEM (Structural } \\
\text { Equation Modeling) }\end{array}$ & & $\begin{array}{l}\text { Joo and Grable (2004); Shim et al. } \\
\text { (2010); Barbic et al. (2019); Dew et al. } \\
(2020)\end{array}$ \\
\hline & & & $\begin{array}{l}\text { Factor Analysis (EFA } \\
\text { (Exploratory Factor } \\
\text { Analysis); CFA } \\
\text { (Confirmatory Factor } \\
\text { Analysis) }\end{array}$ & & $\begin{array}{l}\text { Pak and Chatterjee (2016); Sundarasen } \\
\text { and Rahman (2017); Vosylis and } \\
\text { Erentaite (2019); Antoni et al. (2019) }\end{array}$ \\
\hline & & & Discriminant Analysis & & Grable (2000); Arifin (2017) \\
\hline & & & Mathematical Model & & Bialowolski (2019); Feng et al. (2019) \\
\hline & & Archival $(\mathrm{n}=1)$ & Regression & $\begin{array}{l}\text { OLS (Ordinary Least } \\
\text { Squares) Regression }\end{array}$ & Klopocka (2017) \\
\hline & & Laboratory $(\mathrm{n}=7)$ & Descriptive & & Cho et al. (2016) \\
\hline & & & Correspondence Analysis & & Sonnenberg et al. (2011) \\
\hline & & & $\begin{array}{l}\text { ANOVA (Analysis of } \\
\text { Variance) }\end{array}$ & & $\begin{array}{l}\text { Bailey and kinerson (2005); Cho et al. } \\
\text { (2016); Gerrans and Heaney (2019) }\end{array}$ \\
\hline & & & $\begin{array}{l}\text { MANOVA (Multivariate } \\
\text { Analysis of Variance) }\end{array}$ & & Howlett et al. (2008) \\
\hline & & & Regression & $\begin{array}{l}\text { OLS (Ordinary Least } \\
\text { Squares) Regression }\end{array}$ & Cho et al. (2012); Skimmyhorn (2016) \\
\hline & & & & Linear Regression & Gerrans and Heaney (2019) \\
\hline & Qualitative $(\mathrm{n}=18)$ & $\begin{array}{l}\text { In-Depth } \\
\text { Interviews/ Focus }\end{array}$ & & & $\begin{array}{l}\text { Mugenda et al. (1990); Bharucha } \\
(2018)\end{array}$ \\
\hline
\end{tabular}




\begin{tabular}{|c|c|c|c|c|c|}
\hline & & Groups & & & \\
\hline & Mixed $(n=6)$ & $\begin{array}{l}\text { Survey }+ \\
\text { Interviews/ Focus } \\
\text { groups }\end{array}$ & Regression & Linear Regression & Miotto and parente (2015) \\
\hline & & & & Logistic Regression & Cho et al. (2012); Cineli (2020) \\
\hline & & & & Multiple Regression & Asandimitra and Kautsar (2019) \\
\hline & & & & $\begin{array}{l}\text { OLS (Ordinary Least } \\
\text { Squares) Regression }\end{array}$ & Cho et al. (2012) \\
\hline & & & $\begin{array}{l}\text { SEM (Structural } \\
\text { Equation Modeling) }\end{array}$ & & Bapat (2019) \\
\hline & & & $\begin{array}{l}\text { Factor Analysis EFA } \\
\text { (Exploratory Factor } \\
\text { Analysis);CFA } \\
\text { (Confirmatory Factor } \\
\text { Analysis) }\end{array}$ & & $\begin{array}{l}\text { Miotto and Parente (2015); Bapat } \\
\text { (2019) }\end{array}$ \\
\hline & & & Chi-Square Test & & Vogler et al. (2008) \\
\hline Conceptual $(\mathrm{n}=6)$ & & & & & $\begin{array}{l}\text { Nuspl (1972); McKenna et al. (2003); } \\
\text { Stendardi et al. (2006); Xiao (2008); } \\
\text { Dolan et al. (2012); Van Raaij (2016) }\end{array}$ \\
\hline $\begin{array}{l}\text { Literature Review } \\
(\mathrm{n}=5)\end{array}$ & & & & & $\begin{array}{l}\text { Lusardi and Mitchell (2007); Xiao et } \\
\text { al. (2011); Hastings et al. (2013); } \\
\text { Fernandes et al. (2014) }\end{array}$ \\
\hline \multirow[t]{3}{*}{$\begin{array}{l}\text { Modelling and } \\
\text { Analytical }(n=3)\end{array}$} & Quantitative & Survey & $\begin{array}{l}\text { Bayesian Two-part } \\
\text { Latent Variable } \\
\text { Regression Model }\end{array}$ & & Feng et al. (2019) \\
\hline & & & $\begin{array}{l}\text { Fixed Effects } \\
\text { Regression; Simulation }\end{array}$ & & Lusardi et al. (2017) \\
\hline & & & Probit Regression & & Calvet et al. (2007) \\
\hline $\begin{array}{l}\text { Mixed (Empirical } \\
+ \text { Conceptual) } \\
(\mathrm{n}=1)\end{array}$ & Mixed & Survey & Descriptive & & Doda (2014) \\
\hline
\end{tabular}


Table VIII. Summary table of the antecedents of PFMB and their established relationships

\begin{tabular}{|c|c|c|c|c|}
\hline Typology & Factor (Antecedent) & Sub-Factor & Citations & $\begin{array}{l}\text { Association } \\
\text { with PFMB }\end{array}$ \\
\hline \multirow[t]{16}{*}{ Demographic And Socio-Economic } & Age & & $\begin{array}{l}\text { Allgood and Walstad (2013); Chandra et al. (2017); } \\
\text { Loke (2017a); Eberhardt et al. (2018); Sachitra et al. } \\
\text { (2019); Bapat (2020) }\end{array}$ & Positive \\
\hline & Marital Status & & $\begin{array}{l}\text { Mugenda et al. (1990); Pepin (2019); Sachitra et al. } \\
\text { (2019) }\end{array}$ & Positive \\
\hline & Gender & & $\begin{array}{l}\text { Stendardi et al. (2006)*; Lee and Hanna (2014); Doda } \\
\text { (2014); Chandra et al. (2017); Loke (2017a); Bharucha } \\
\text { (2018); Cho et al. (2016) }\end{array}$ & Significant \\
\hline & Income & & $\begin{array}{l}\text { Mugenda et al. (1990); Perry and Morris (2005); } \\
\text { McHugh and Rob Ranyard (2012); Gunay et al. (2014); } \\
\text { Loke (2015); Rodrigues et al. (2016) }\end{array}$ & Positive \\
\hline & & & Grable et al. (2009) & Insignificant \\
\hline & Education & & $\begin{array}{l}\text { Gorniak (1999); McHugh and Rob Ranyard (2012); } \\
\text { Gunay et al. (2014); Chandra et al. (2017); Loke (2017a) }\end{array}$ & Positive \\
\hline & & & Loke (2015) & Insignificant \\
\hline & Job Status & & $\begin{array}{l}\text { Gorniak (1999); Lai and Tan (2009); Gunay et al. } \\
\text { (2014) }\end{array}$ & Positive \\
\hline & Household Size & & Mugenda et al. (1990); Calvet et al. (2007) & Positive \\
\hline & & & Borda and Kowalczyk-Rólczyńska (2016) & Negative \\
\hline & Occupation & & Bapat (2020) & Positive \\
\hline & Race/ Ethnicity & & Hanna et al. (2015); Loke (2017a) & Significant \\
\hline & Family Income & & Gorniak (1999); Sachitra et al. (2019) & Positive \\
\hline & Family Structure & & $\begin{array}{l}\text { Scannell (1990); Borda and Kowalczyk-Rólczyńska } \\
(2016)\end{array}$ & Positive \\
\hline & $\begin{array}{l}\text { Generational } \\
\text { Complexity (Nuclear/ } \\
\text { Joint family) }\end{array}$ & & Singh and Bhandari (2012) & Significant \\
\hline & Length of Marriage & & Godwin and Carroll (1986) & Positive \\
\hline
\end{tabular}




\begin{tabular}{|c|c|c|c|c|}
\hline & Home Ownership & & Copur and Gutter (2019) & Positive \\
\hline & Life Cycle & & $\begin{array}{l}\text { Mullis and Schnittgrund (1982); Nuspl (1972)*; Miotto } \\
\text { and Parente (2015) }\end{array}$ & Significant \\
\hline & $\begin{array}{l}\text { Earning Disparities } \\
\text { between Partners }\end{array}$ & & $\begin{array}{l}\text { Vogler et al. (2006); Sonnenberg et al. (2011); Lott } \\
\text { (2017); Kulic et al. (2019); Pepin (2019); Cineli (2020) }\end{array}$ & Significant \\
\hline & $\begin{array}{l}\text { Gender Egalitarian } \\
\text { Beliefs }\end{array}$ & & Cineli $(2020)$ & Significant \\
\hline & $\begin{array}{l}\text { Gender of the higher } \\
\text { earner between } \\
\text { Partners }\end{array}$ & & Pepin (2019) & Significant \\
\hline & Relationship Type & & $\begin{array}{l}\text { Vogler et al. (2006); Lyssens-Danneboom and } \\
\text { Mortelmans (2014); Lott (2017) }\end{array}$ & Significant \\
\hline & $\begin{array}{l}\text { Female Labour } \\
\text { Market Participation }\end{array}$ & & $\begin{array}{l}\text { Godwin and Carroll (1986); Vogler et al. (2006); } \\
\text { Bharucha (2018) }\end{array}$ & Significant \\
\hline & $\begin{array}{l}\text { Contribution to } \\
\text { Family Income/ } \\
\text { Breadwinning Role }\end{array}$ & & $\begin{array}{l}\text { Lyssens-Danneboom and Mortelmans (2014); Bharucha } \\
\text { (2018); Kulic et al. (2019) }\end{array}$ & Significant \\
\hline \multirow[t]{7}{*}{ Psychological } & Cognitive Abilities & $\begin{array}{l}\text { Numeracy } \\
\text { Experience } \\
\text { Based } \\
\text { Knowledge }\end{array}$ & Eberhardt et al. (2018); Topa et al. (2018) & Positive \\
\hline & $\begin{array}{l}\text { Financial Risk } \\
\text { Tolerance }\end{array}$ & & $\begin{array}{l}\text { Grable (2000); Joo and Grable (2000); Bailey and } \\
\text { Kinerson (2005); Bapat (2020) }\end{array}$ & Positive \\
\hline & Financial Attitude & & $\begin{array}{l}\text { Kidwell et al. (2003); Kidwell and Turrisi (2004); Gunay } \\
\text { et al. (2014); Barbic et al. (2019); Bapat (2020); Ho and } \\
\text { Lee (2020) }\end{array}$ & Positive \\
\hline & Self -Regulation & & Howlett et al. (2008) & Positive \\
\hline & Locus of Control & & $\begin{array}{l}\text { Bapat (2020); Kidwell et al. (2003); Lea et al. (1995); } \\
\text { Arifin (2017); Perry and Morris (2005); McNair et al. } \\
\text { (2016) }\end{array}$ & Positive \\
\hline & & & Grable et al. (2009) & Negative \\
\hline & Financial Self & & Farrell et al. (2016); Gamst-Klaussen et al. (2019); & Positive \\
\hline
\end{tabular}




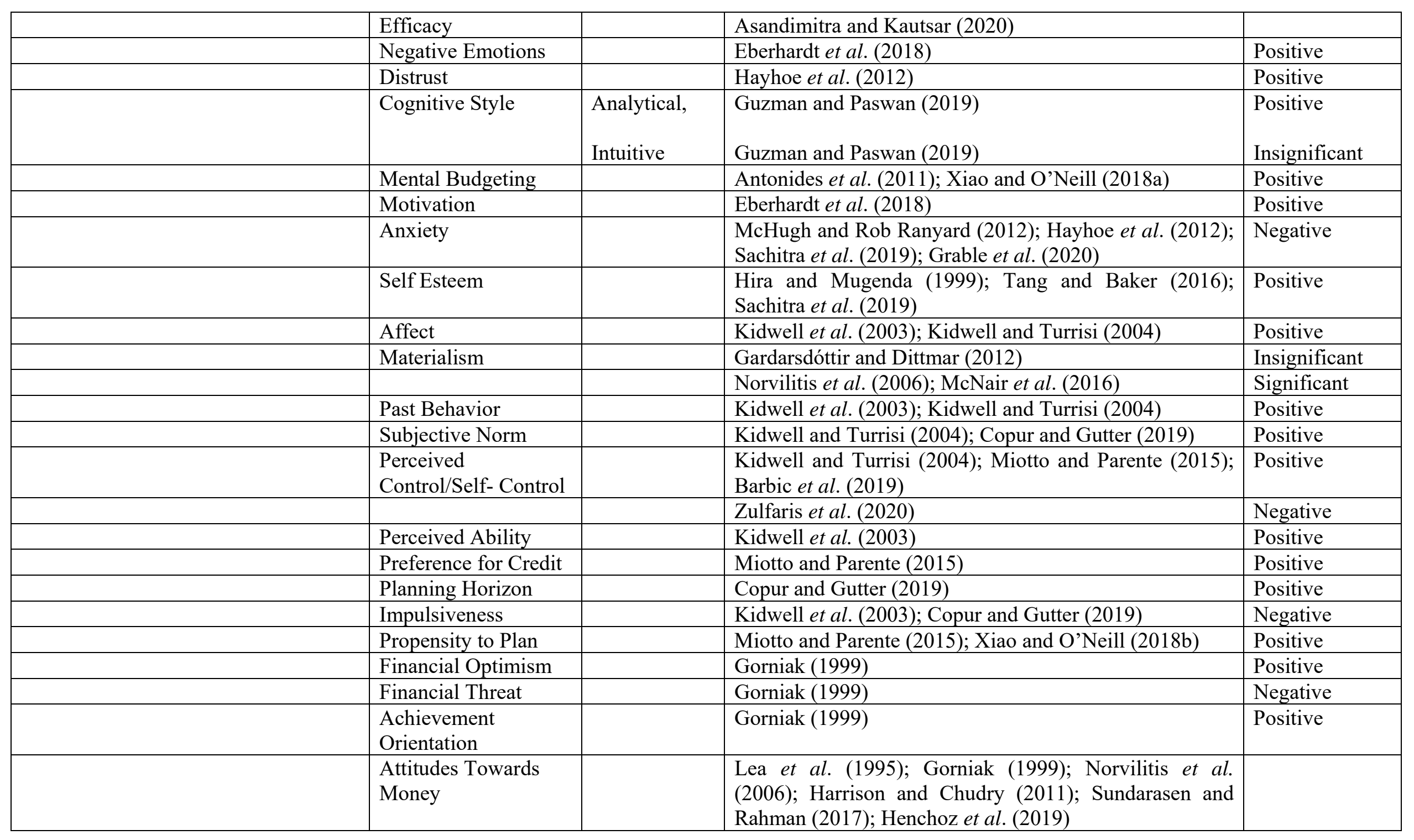




\begin{tabular}{|c|c|c|c|c|}
\hline & $\begin{array}{l}\text { Time Orientation/ } \\
\text { Present Bias }\end{array}$ & & $\begin{array}{l}\text { Lea et al. (1995); Antonides et al. (2011); Xiao and Porto } \\
\text { (2019); Guzman and Paswan (2019); Hastings and } \\
\text { Mitchell (2020) }\end{array}$ & Positive \\
\hline & & & Howlett et al. (2008) & Negative \\
\hline & Framing Effect & & Cho et al. (2016) & Significant \\
\hline & Self- Confidence & & $\begin{array}{l}\text { Kłopocka (2016); Chandra et al. (2017); Białowolski } \\
\text { (2019); Sachitra et al. (2019) }\end{array}$ & Positive \\
\hline & $\begin{array}{l}\text { Emotional } \\
\text { Intelligence }\end{array}$ & & Asandimitra and Kautsar (2020) & Positive \\
\hline & $\begin{array}{l}\text { Self-Other } \\
\text { Orientation }\end{array}$ & & Guzman and Paswan (2019) & Positive \\
\hline & Psychological Type & $\begin{array}{l}\text { Extravert; } \\
\text { Introvert; } \\
\text { Sensing; } \\
\text { Intuitive; } \\
\text { Thinking; } \\
\text { Feeling; } \\
\text { Judging; } \\
\text { Perceiving }\end{array}$ & McKenna et al. (2003)* & Significant \\
\hline & Procrastination & & Gamst-Klaussen et al. (2019) & Negative \\
\hline \multirow[t]{2}{*}{ Personality } & & & $\begin{array}{l}\text { Xu et al. (2015); Gerrans and Heaney (2016); Xu et al. } \\
\text { (2017) }\end{array}$ & Positive \\
\hline & & & Harrison and Chudry (2011) & Negative \\
\hline \multirow[t]{2}{*}{ Social } & $\begin{array}{l}\text { Family Financial } \\
\text { Socialization }\end{array}$ & & $\begin{array}{l}\text { Lea et al. (1995); Shim et al. (2009); Grinstein-Weiss et } \\
\text { al. (2011); Cho et al. (2012); Grinstein-Weiss et al. } \\
\text { (2012); Sundarasen and Rahman (2017); Fulk and White } \\
\text { (2018); Vosylis and Erentaite (2019); Sachitra et al. } \\
\text { (2019); Antoni et al. (2019); Lebaron et al. (2020) }\end{array}$ & Positive \\
\hline & Peer Influence & & Bamforth et al. (2018); Zulfaris et al. (2020) & Negative \\
\hline Financial Literacy & Objective FL & & $\begin{array}{l}\text { Hilgert et al. (2003); Norvilitis et al. (2006); Lusardi and } \\
\text { Mitchell (2007)*; Howlett et al. (2008); Lusardi (2008); } \\
\text { Lusardi and Mitchell (2008); Grable et al. (2009); }\end{array}$ & Positive \\
\hline
\end{tabular}




\begin{tabular}{|c|c|c|c|c|}
\hline & & & $\begin{array}{l}\text { Antonides et al. (2011); Harrison and Chudry (2011); } \\
\text { Boon et al. (2011); Lusardi and Mitchell (2011b); } \\
\text { Hastings et al. (2013)*; Allgood and Walstad (2013); } \\
\text { Lee and Hanna (2014); Navickas et al. (2014); Arifin } \\
\text { (2017); Loke (2017a); Lusardi et al. (2017); Nejad and } \\
\text { Javid (2018); Topa et al. (2018); Grable et al. (2019); } \\
\text { Bapat (2019); Sachitra et al. (2019); Feng et al. (2019); } \\
\text { Barbic et al. (2019); Bapat (2020); Bialowolski et al. } \\
\text { (2020); Zulfaris et al. (2020); Lusardi et al. (2020); } \\
\text { Hastings and Mitchell (2020) }\end{array}$ & \\
\hline & & & Pak and Chatterjee (2016) & Negative \\
\hline & Subjective FL & & Sundarasen and Rahman (2017) & Positive \\
\hline Environmental & & Genetic & Xu et al. (2017) & Significant \\
\hline Financial Education & & & $\begin{array}{l}\text { Godwin and Carroll (1986); Mandell and Klein (2009); } \\
\text { Skimmyhorn (2016); Gerrans and Heaney (2016); Fulk } \\
\text { and White (2018); Ho and Lee (2020); Mandell (2008); }\end{array}$ & Positive \\
\hline & & & Fernandes et al. (2014) & Insignificant \\
\hline Professional Financial Advice & & & Topa et al. (2018); Moreland (2018); Bapat (2019) & Positive \\
\hline Technological & Fin-Tech & & Bapat (2019); Panos and Wilson (2020) & Positive \\
\hline Communication & & & Mugenda et al. (1990) & Positive \\
\hline Financial Information & & & $\begin{array}{l}\text { McHugh and Rob Ranyard (2012); Asandimitra and } \\
\text { Kautsar (2020) }\end{array}$ & Positive \\
\hline Financial Experience & & & Lee and Hanna (2014) & Positive \\
\hline Financial Resources & & & Rodrigues et al. (2016) & \\
\hline Situational & & & $\begin{array}{l}\text { Miotto and Parente (2015); West and Worthington } \\
\text { (2019) }\end{array}$ & Significant \\
\hline Cultural & & & Grable et al. (2009); Henchoz et al. (2019) & Significant \\
\hline Financial Vulnerability & & & Hoffman and McNair (2019) & Negative \\
\hline
\end{tabular}

Note: The studies marked with * are conceptual and not empirical, but contribute towards the literature conceptually. Also, the directionality of relationships (positive or negative) has been reported as mentioned in the studies. All the studies do not report the direction of the association, ergo, only significance/insignificance has been reported. Different studies on a single sub-factor might have shown either positive, negative or insignificant results which implies a non-consensus. 
Table IX. Summary table of the consequences of PFMB and their established relationships

\begin{tabular}{|l|l|l|}
\hline Outcome Variable (Consequence) & Citations & Association with PFMB \\
\hline Financial Satisfaction & $\begin{array}{l}\text { Mugenda et al. (1990); Scannell (1990); Joo } \\
\text { and Grable (2004); Xiao et al. (2014); Gunay et } \\
\text { al. (2015); Xiao and Porto (2017); Xiao and O' } \\
\text { Neill (2018b); Spuhlera and Dew (2019) }\end{array}$ \\
\hline Quality Of Life & Mugenda et al. (1990); Dew et al. (2020) & Positive \\
\hline Relationship Satisfaction & $\begin{array}{l}\text { Clearwater and Harvey (1988); Vogler et al. } \\
\text { (2008); Bharucha (2018); Kulic et al. (2019); } \\
\text { Baryła-Matejczuk et al. (2020) }\end{array}$ & \\
\hline Financial Status & Gunay et al. (2015) & Positive \\
\hline Financial Access & Birkenmaier and Fu (2019) & Positive \\
\hline Financial Vulnerability/Financial Fragility & Daud et al. (2019); Lusardi et al. (2020) & Negative \\
\hline Financial Well-Being & $\begin{array}{l}\text { Xiao (2008)*; Xiao et al. (2015); Xiao (2015)*; } \\
\text { Xiao and O' Neill (2016); Xiao and Porto } \\
\text { (2017); Riitsalu and Murakas (2018); Baryła- } \\
\text { Matejczuk et al. (2020) }\end{array}$ & Positive \\
\hline Financial Anxiety & Vosylis and Erentaite (2019) & Negative \\
\hline Happiness & Spuhlera and Dew (2019) & Positive \\
\hline Net Worth & Titus et al. (1989) & Positive \\
\hline Financial Resilience & Lusardi et al. (2020) & Positive \\
\hline
\end{tabular}

Note: The studies marked with * are conceptual and not empirical, but contribute towards the literature conceptually. Out of 160 studies, this table contains those studies that relate to the consequences of PFMB. 
Table X. Research agenda for PFMB

\begin{tabular}{|c|c|c|c|}
\hline Research Gap & & Future Research Questions & References \\
\hline \multirow[t]{3}{*}{ Conceptualization } & 1 & $\begin{array}{l}\text { Whether PFMB is a part of finance, a topic within family or consumer } \\
\text { sciences or it is a standalone topic of research? }\end{array}$ & Altfest (2004); Schuchardt et al. (2007) \\
\hline & 2 & $\begin{array}{l}\text { What is the scope of personal finance construct and how can it be } \\
\text { defined universally? }\end{array}$ & Schuchardt et al. (2007); Xiao and Tao (2020) \\
\hline & 3 & What are the different terms used for "personal finance"? & Xiao and Tao (2020) \\
\hline \multirow{4}{*}{ Theories } & 4 & $\begin{array}{l}\text { How can theoretical approaches used in multiple disciplines can } \\
\text { inform the stage at which people are willing and able to alter their } \\
\text { various financial behaviors? }\end{array}$ & $\begin{array}{l}\text { Schuchardt et al. (2007); Xiao (2008); Gamst-Klaussen } \\
\text { et al. (2019) }\end{array}$ \\
\hline & 5 & $\begin{array}{l}\text { What is the theoretical foundation for the linkage between financial } \\
\text { education, personal financial behavior and life satisfaction? }\end{array}$ & Xiao (2008); Xiao et al. (2011); Fernandes et al. (2014) \\
\hline & 6 & $\begin{array}{l}\text { Develop socio-psychological theories as such to support behavioral } \\
\text { biases due to culture and other social factors. }\end{array}$ & Triandis (1994) \\
\hline & 7 & $\begin{array}{l}\text { Apply the TPB and the TTM on diversified behaviors and } \\
\text { populations. }\end{array}$ & Kidwell and Turrisi (2004); Bapat, (2020) \\
\hline \multirow{4}{*}{$\begin{array}{l}\text { Antecedents of } \\
\text { PFM }\end{array}$} & 8 & $\begin{array}{l}\text { What are the processes through which various demographic and } \\
\text { socio-economic, social, psychological, cultural, situational and } \\
\text { technological factors differentially relate to a set of financial } \\
\text { outcomes? }\end{array}$ & Copur and Gutter (2019) \\
\hline & 9 & What are the possible factors and sub-factors of PFMB? & Copur and Gutter (2019), Bapat (2020) \\
\hline & 10 & $\begin{array}{l}\text { Re-examine through future research the impact of various factors on } \\
\text { financial management behaviors such as income level, education, } \\
\text { household size, self-control, personality traits, LOC, financial } \\
\text { education and FL. }\end{array}$ & $\begin{array}{l}\text { Mugenda et al. (1990); Gorniak (1999); Kidwell and } \\
\text { Turrisi (2004); Perry and Morris (2005); Grable et al. } \\
\text { (2009); Xu et al. (2015); Pak and Chatterjee (2016); } \\
\text { Zulfaris et al. (2020) }\end{array}$ \\
\hline & 11 & $\begin{array}{l}\text { Examine the relationship between fintech and various consumer } \\
\text { financial topics. }\end{array}$ & Xiao and Tao (2020) \\
\hline
\end{tabular}




\begin{tabular}{|c|c|c|c|}
\hline & 12 & $\begin{array}{l}\text { What are the antecedents of financial knowledge (Objective vs } \\
\text { subjective) as a pivotal factor for sound financial behavior? }\end{array}$ & Grable et al. (2009) \\
\hline & 13 & $\begin{array}{l}\text { Explore the hierarchical financial behavior on other behaviors (other } \\
\text { than budgeting) such as saving, investing, borrowing, etc. }\end{array}$ & Xiao and O’ Neill (2018a) \\
\hline \multirow[t]{4}{*}{ Mediators of PFM } & 14 & $\begin{array}{l}\text { How demographics indirectly affect financial outcomes via financial } \\
\text { socialization processes? }\end{array}$ & Shim et al. $(2009,2010)$ \\
\hline & 15 & $\begin{array}{l}\text { What are the pathways between various factors and sound financial } \\
\text { management behavior? }\end{array}$ & Barbic et al. (2019) \\
\hline & 16 & $\begin{array}{l}\text { What is the effect of a mediating relationship of financial attitude } \\
\text { between financial socialization and financial behavior? }\end{array}$ & Shim et al. (2010) \\
\hline & 17 & $\begin{array}{l}\text { What is the effect of psychological factors as mediators between } \\
\text { demographics and financial behavior? }\end{array}$ & Bapat (2020) \\
\hline \multirow[t]{6}{*}{$\begin{array}{l}\text { Moderators of } \\
\text { FPM }\end{array}$} & 18 & $\begin{array}{l}\text { What are the interactions of social categorizations such as } \\
\text { race/ethnicity or socio-economic status in couples' financial systems } \\
\text { and relational outcomes? }\end{array}$ & Pepin (2019); Cineli (2020) \\
\hline & 19 & $\begin{array}{l}\text { Re-examine the moderating effects of FL on the relationship between } \\
\text { financial attitude and financial behavior. }\end{array}$ & Eagly and Chaiken, (1993); Barbic et al. (2019) \\
\hline & 20 & $\begin{array}{l}\text { What are the interaction effects of professional financial advice with } \\
\text { FL and financial behavior? }\end{array}$ & Topa et al. (2018) \\
\hline & 21 & What is the moderating role of culture on FL and behavior? & Grable et al. (2009) \\
\hline & 22 & $\begin{array}{l}\text { What is the moderating role of additional psychological factors in } \\
\text { changing the relationship between demographics, FL, social factors } \\
\text { and financial behavior? }\end{array}$ & Miotto and Parente (2015) \\
\hline & 23 & $\begin{array}{l}\text { How use of fin-tech may influence FL level and its interaction effect } \\
\text { towards financial behavior? }\end{array}$ & Bapat (2019); Morgan and Trinh (2019) \\
\hline \multirow[t]{3}{*}{$\begin{array}{l}\text { Consequences of } \\
\text { PFM }\end{array}$} & 24 & $\begin{array}{l}\text { Whether there is an existence of linear relationship between income, } \\
\text { PFM and happiness? }\end{array}$ & Stevenson and Wolfers, 2013 \\
\hline & 25 & $\begin{array}{l}\text { Whether relationship exists between financial attitude, financial } \\
\text { behavior and financial satisfaction? }\end{array}$ & Xiao et al. (2014); Spuhlera and Dew (2019) \\
\hline & 26 & $\begin{array}{l}\text { Examine the relationship between financial behavior, financial access } \\
\text { and financial well-being. }\end{array}$ & Birkenmaier and Fu (2019) \\
\hline
\end{tabular}




\begin{tabular}{|c|c|c|c|}
\hline & 27 & Does FL and better financial behavior results in financial resilience? & Lusardi et al. (2020) \\
\hline & 28 & What are the consequences of PFM behavior? & Xiao et al. (2014) \\
\hline \multirow[t]{2}{*}{ Measures of PFM } & 29 & $\begin{array}{l}\text { How can the construct of PFMB be measured/ Which financial } \\
\text { behaviors constitute it? }\end{array}$ & Xiao (2008); Dew and Xiao (2011) \\
\hline & 30 & Develop age or life situations specific PFMB scales. & Xiao (2008) \\
\hline \multirow[t]{6}{*}{$\begin{array}{l}\text { Research } \\
\text { methodology }\end{array}$} & 31 & $\begin{array}{l}\text { Extend the research to include more conceptual papers focusing on } \\
\text { better conceptualization of the PFMB construct. }\end{array}$ & Schuchardt et al. (2007) \\
\hline & 32 & $\begin{array}{l}\text { Add studies that are qualitative in nature and collect data from } \\
\text { secondary sources as well. }\end{array}$ & Boon et al. (2011); Navickas et al. (2014) \\
\hline & 33 & Use of SEM in future studies and mixed methodology of research. & $\begin{array}{l}\text { Miotto and Parente (2015); Birkenmaier and Fu (2019); } \\
\text { Bapat (2020); }\end{array}$ \\
\hline & 34 & $\begin{array}{l}\text { How can the causality issue between FL and financial behaviour be } \\
\text { resolved? }\end{array}$ & Lusardi and Mitchell (2014) \\
\hline & 35 & $\begin{array}{l}\text { How can the causality issue between FL and financial experience be } \\
\text { resolved? }\end{array}$ & Frijns et al. (2014) \\
\hline & 36 & $\begin{array}{l}\text { Explore the causality issue between financial behavior and financial } \\
\text { access. }\end{array}$ & Xiao et al. (2010) \\
\hline
\end{tabular}




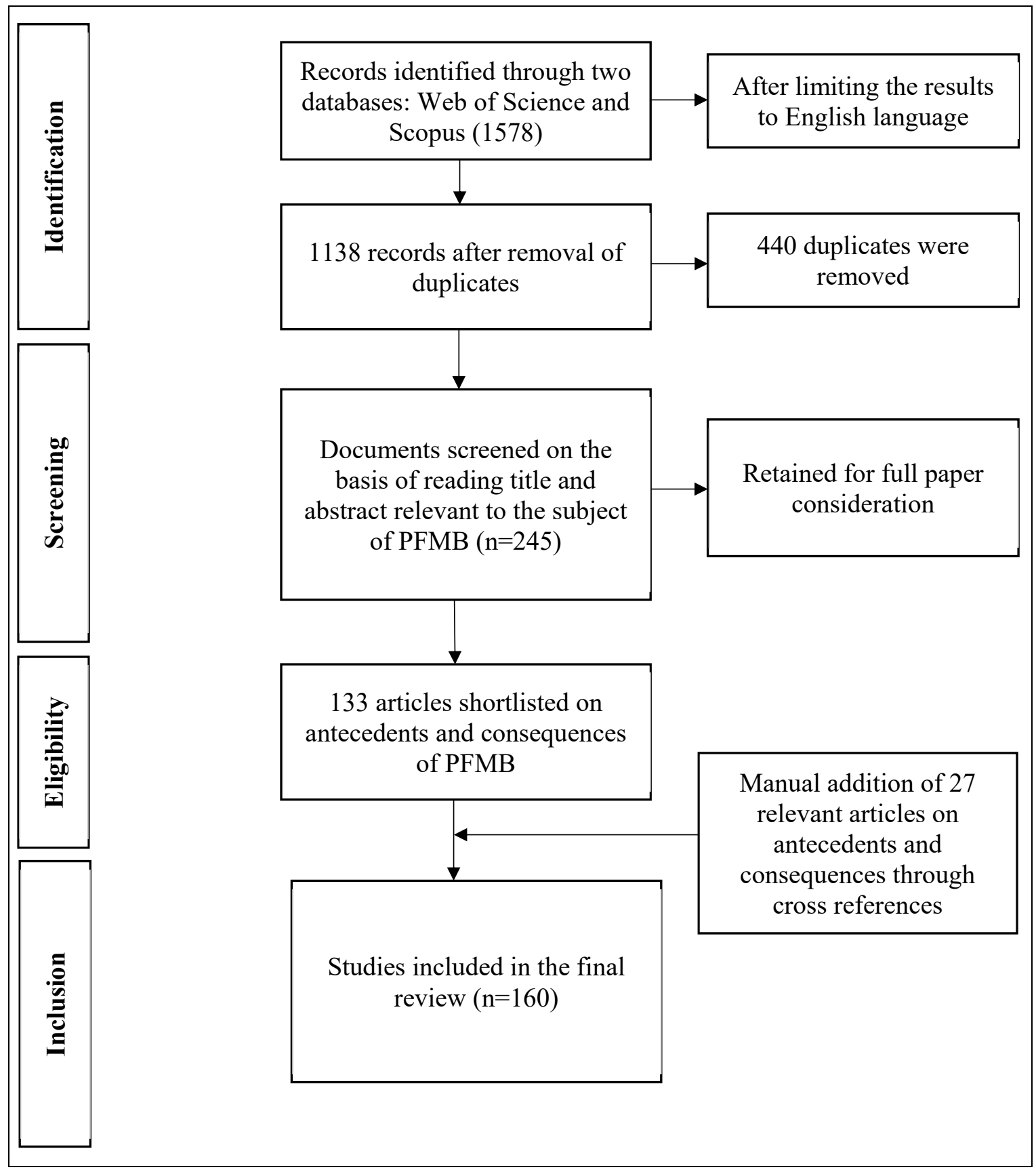

Figure 1. Retrieval and selection of articles 


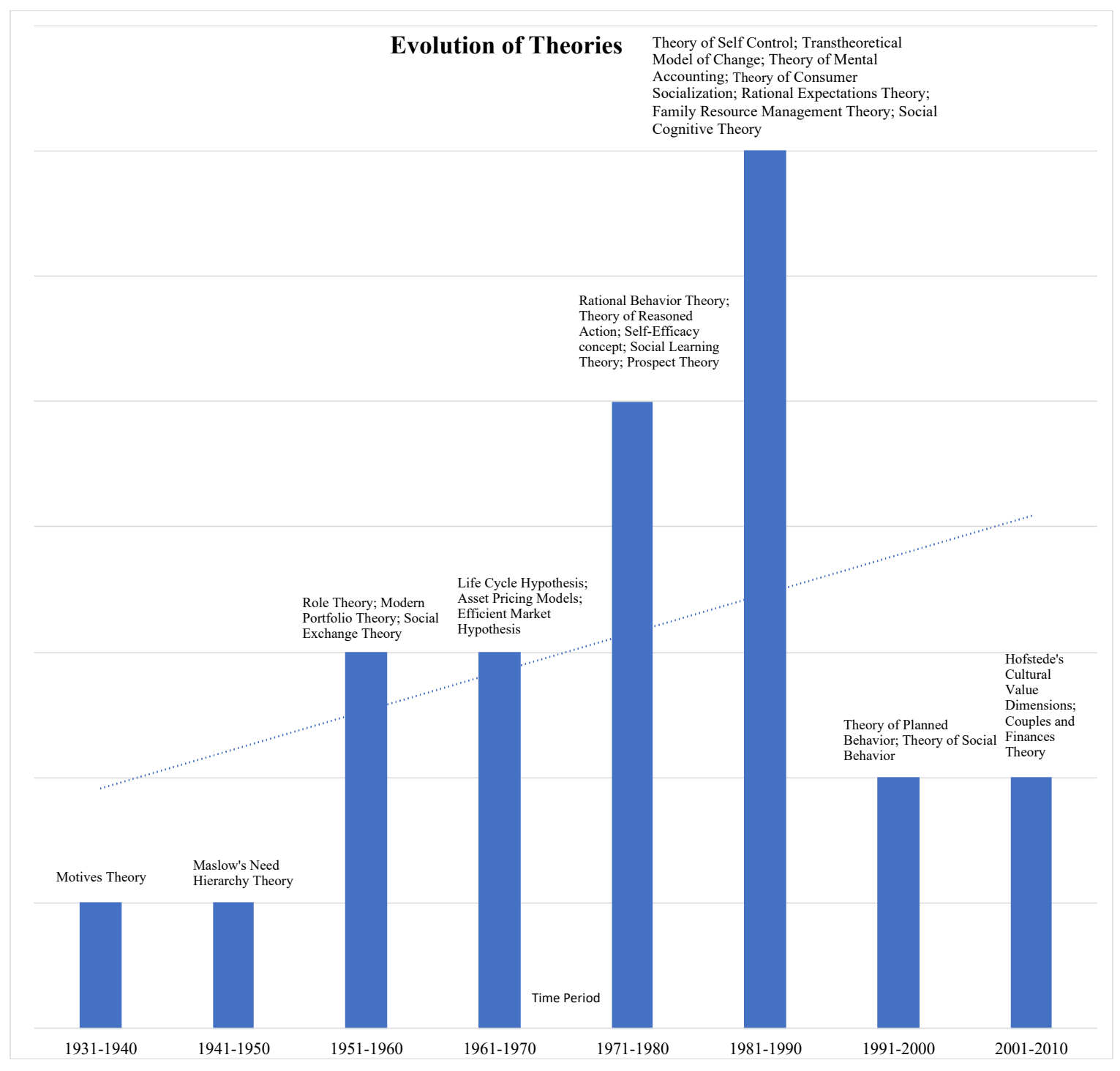

Figure 2. Evolution of theories on PFMB 


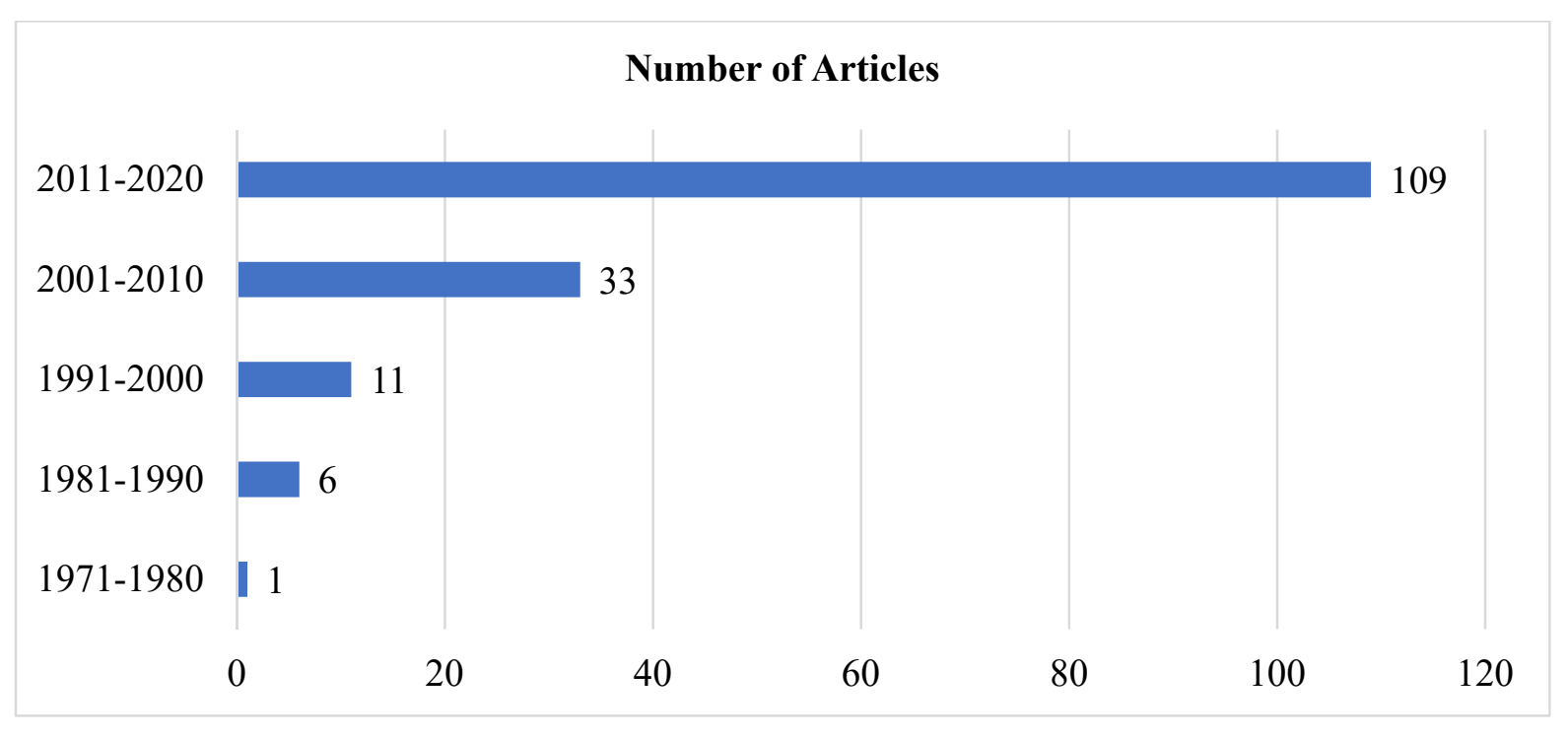

Figure 3. Publication trend of 160 articles 


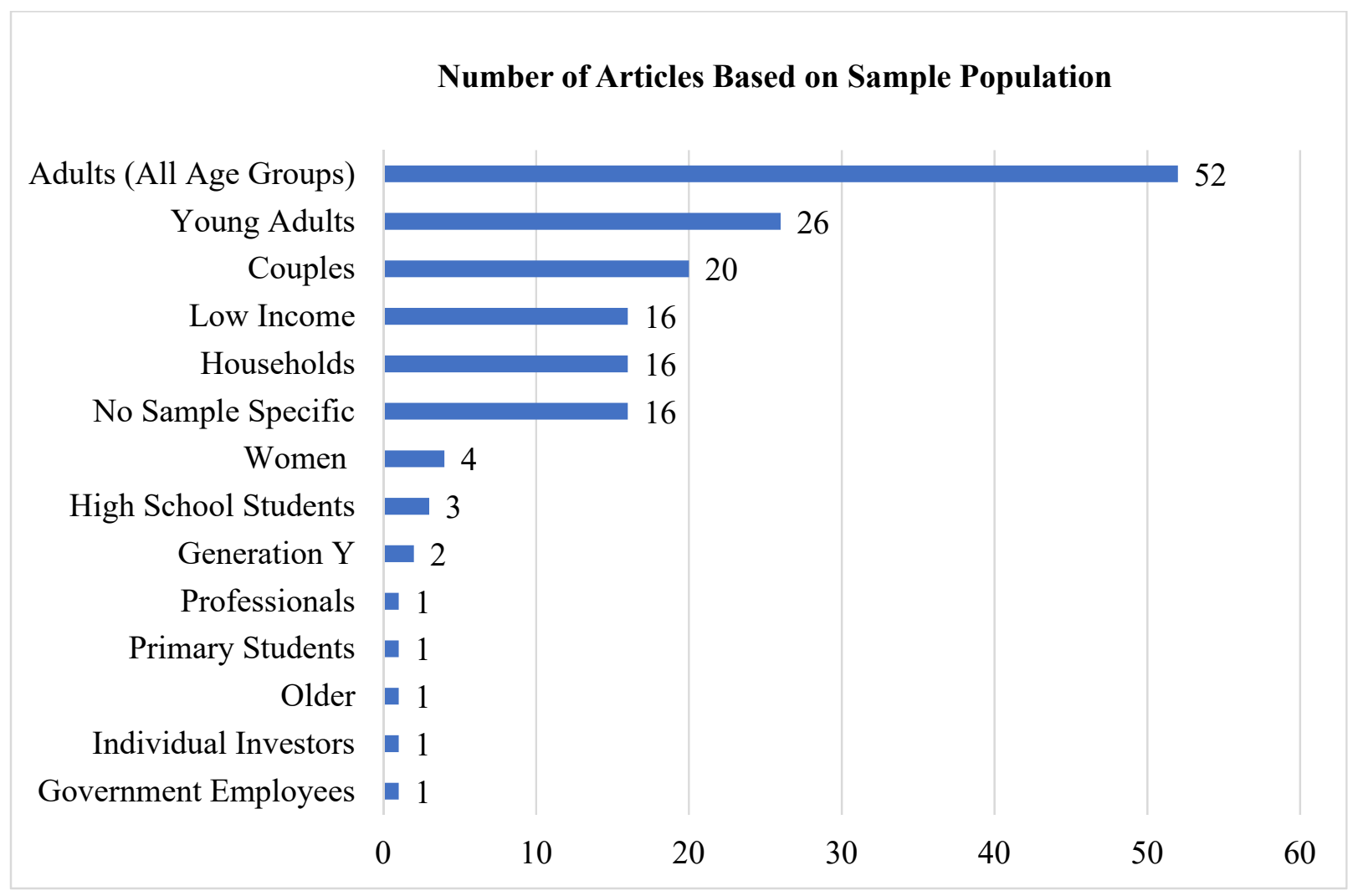

Figure 4. Overview of sample population used in 160 studies 


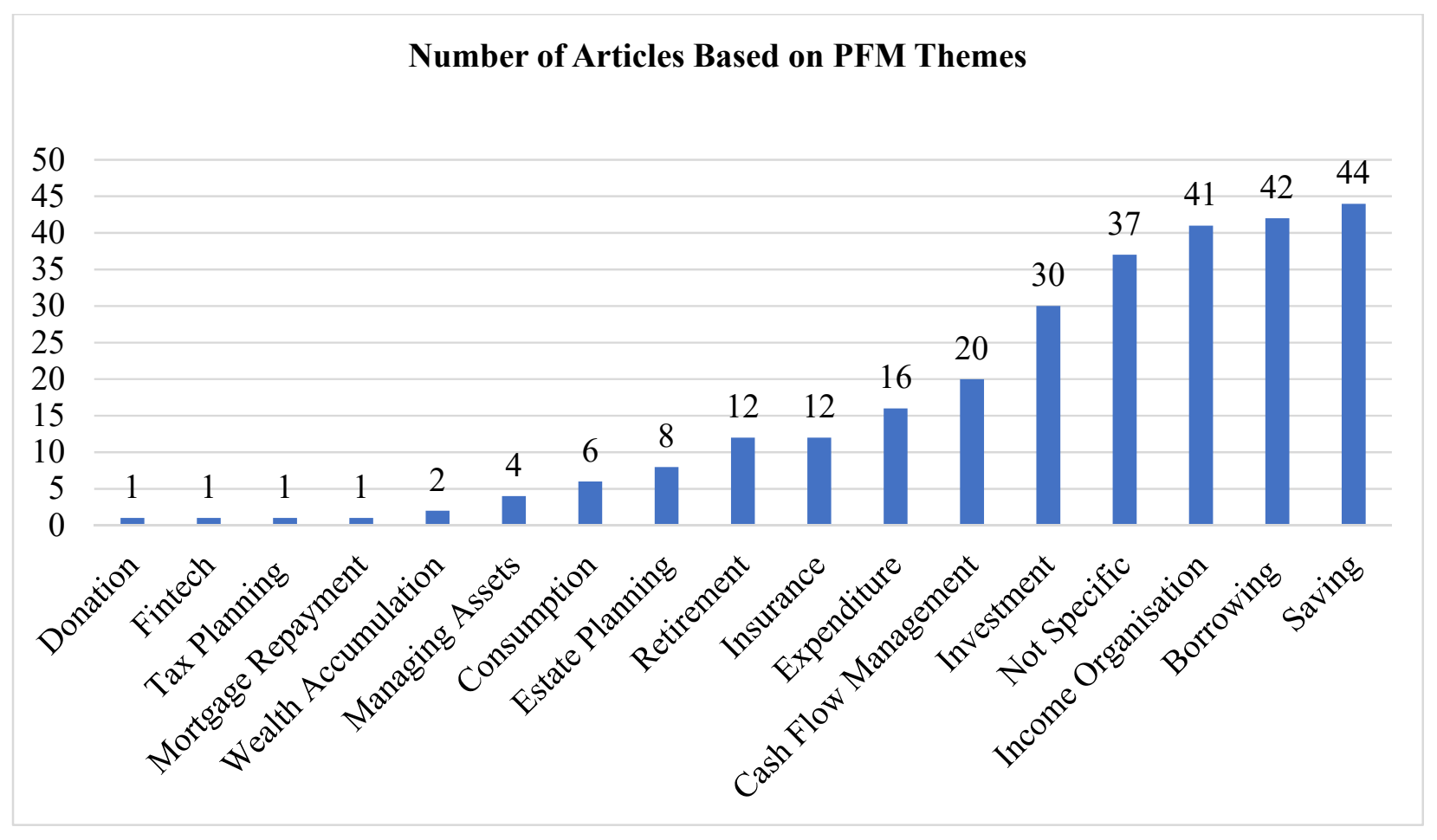

Figure 5. Number of publications based on PFMB themes across 160 studies 


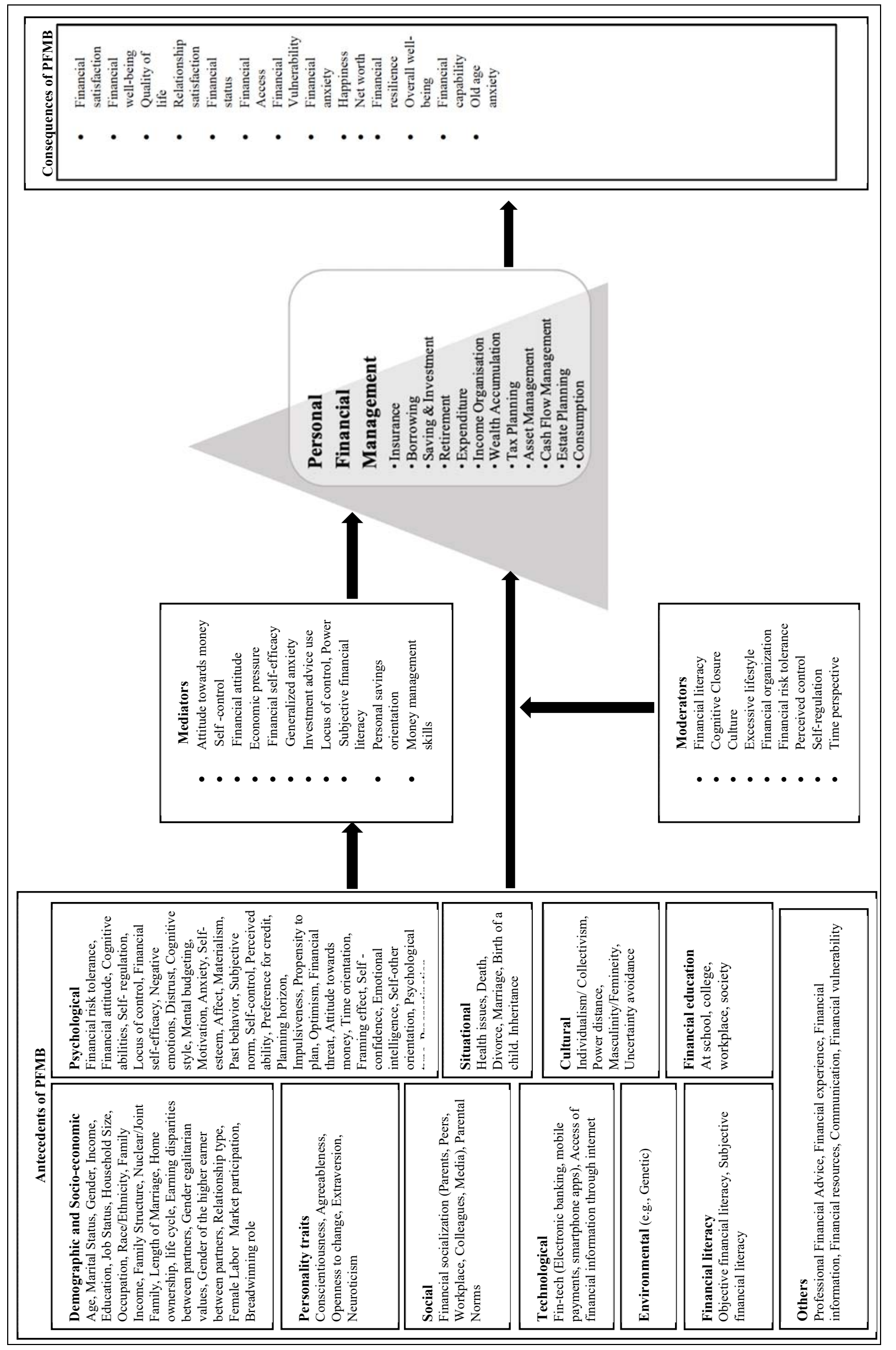

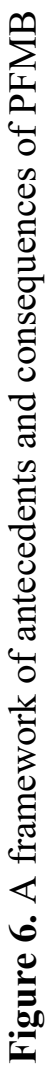

